\title{
Ortaokul Öğrencilerinin Müzik Dersi ve Müzik Öğretmenine İlişkin Algılarının Metaforik Analizi
}

\author{
İlker TEZ* \\ Güzel Sanatlar Lisesi, Bahçelievler Mahallesi, Birko Caddesi, Niğde / Türkiye
}

Doç. Dr. Mehtap AYDINER-UYGUN

Ömer Halisdemir Üniversitesi, Eğitim Fakültesi, Müzik Eğitimi Anabilim Dalı, Niğde/ Türkiye

\section{$\ddot{O} z$}

$\mathrm{Bu}$ çalışmanın amacı, ortaokul öğrencilerinin müzik dersi ve müzik öğretmenine ilişkin algılarının metaforlar yoluyla analiz edilmesidir. Araştırmanın çalışma grubunu, 2014-2015 eğitim-öğretim yılında Niğde ili merkez ilçesindeki ortaokul 5, 6, 7 ve 8. sınıflarda öğrenim görmekte olan 972 öğrenci oluşturmaktadır. Çalışmanın verileri, ortaokul öğrencilerinin müzik dersi ve müzik öğretmenine ilişkin sahip oldukları algıları ortaya koymak amacıyla "Müzik dersi ... gibidir. Çünkü ... ” ve “Müzik öğretmeni ... gibidir. Çünkü ... ” ifadelerini tamamlamaları istenen bir form aracılığıyla elde edilmiştir. Çalışma sonucunda müzik dersine ilişkin kavramsal kategorilerden "eğlendiren ve mutluluk veren bir ders olarak müzik dersi" ( $\mathrm{f}=558$, \%57.41) kategorisinin öğrencilerin en sık katılım gösterdiği kategori olduğu bulunmuştur. Bu kategoriyi "arındıran, dinlendiren ve huzur veren bir ders olarak müzik dersi" ( $\mathrm{f}=98, \% 10.08)$, "karmaşık bir ders olarak müzik dersi” ( $\mathrm{f}=87, \%$ \% 8.95) ile "zengin öğrenme durumlarını içeren bir ders olarak müzik dersi" ( $\mathrm{f}=54, \% 5.55)$ kategorilerinin takip ettiği tespit edilmiştir. Çalışma sonucunda müzik öğretmenine 
ilişkin kavramsal kategorilerden ilk sırada yer alan kategorinin "seven, güven veren ve koruyan bir kişi olarak müzik öğretmeni” ( $\mathrm{f}=246$, \%25.31) kategorisi olduğu belirlenmiştir. Bu kategoriyi "sanatçı kişiliği ile müzik öğretmeni” ( $\mathrm{f}=224, \%$ 23.04) ve "hayranlık duyulan bir kişi olarak müzik öğretmeni” (f=96, \%9.88) kategorilerinin izlemekte olduğu bulunmuştur.

Anahtar Kelimeler: Müzik dersi; Müzik öğretmeni; Ortaokul öğrencileri; Metafor.

\title{
A Metaphorical Analysis of Middle-School Students' Perceptions on Music Lesson and Music Teacher
}

\begin{abstract}
The purpose of this study was to analyze middle-school students' perceptions on music lesson and music teacher through metaphors. The study group comprised of 972 students in grades 5, 6, 7 and 8 in middle schools in the central province of Niğde during the 2014-2015 school year. In order to determine the perceptions of middle-school students on music lesson and music teacher, the research data were collected through forms requiring the students to complete the expressions such as "Music lesson are like ..., because ..." and "Music teacher are like ..., because ...". The category of "Music lesson as an entertaining, relaxing and uplifting lesson" ( $\mathrm{f}=558,57.41 \%)$ was found to be the category the students most often chose. It was found that the categories of "Music lesson as a purifying, relaxing and peaceful lesson" ( $\mathrm{f}=98$, $10.08 \%)$, "Music lesson as a complicated lesson" ( $\mathrm{f}=87,8.95 \%)$ and "Music lesson as a lesson containing rich learning" ( $\mathrm{f}=54,5.55 \%)$ were chosen less often. The top conceptual category regarding music teacher was found to be the category of "Music teacher as a person who loves, cares and boosts confidence" ( $\mathrm{f}=246,25.31 \%$ ). It was found that the categories of "Music teacher with his or her own artistic personality" ( $\mathrm{f}=224,23.04 \%)$ and "Music teacher as a person who is admired" $(\mathrm{f}=96,9.88 \%)$ were chosen less often.
\end{abstract}

Keywords: Music lesson; Music teacher; Middle-school students; Metaphor. 


\section{Extended Summary}

\section{Purpose}

In middle schools, music lessons help students to learn musical culture, to create and develop a musical taste and to tend towards music through listening to, singing, playing and producing music. For music lessons to have the greatest effect, it depends on the learning-teaching setting and the music teacher. In this context, it is important to determine the perceptions of the students on music lessons and music teachers. In determining these perceptions, metaphors can be an effective instrument. The purpose of this study is to analyze the middle-school students' perceptions of music lessons and music teachers through metaphors. In the study, accordingly, the answers to these questions were sought:

a. What are the metaphors of middle-school students on the topic of music lesson?

b. What are the metaphors of middle-school students on the topic of music teacher?

c. Under which conceptual categories can the metaphors about music lesson be categorized in terms of their common features?

d. Under which conceptual categories can the metaphors about music teachers be categorized in terms of their common features?

\section{Method}

This study has a mixed research design. The study group comprised of 972 students in grades 5, 6, 7 and 8 in six middle schools, which were chosen from twelve middle schools through the cluster sampling method, in the central province of Niğde during the 2014-2015 school year.

In order to determine the perceptions of middle-school students on music lessons and music teachers, the research data were collected through a form requiring the students to complete the expressions such as "Music lesson is like ..., because ..." and "Music teacher is like ..., because ...". The form was implemented by researchers visiting the schools, explaining the data collection tool within each classroom. The data of the study were analyzed using the content analysis method. Accordingly, the data obtained were analyzed in five stages: encoding the valid metaphors and sorting out the invalid metaphors; compiling the sample metaphoric expressions; developing 
categories by theme; establishing the validity and reliability; and analyzing the qualitative data through the SPSS program by turning them into quantitative data.

\section{Results and Discussion}

As a result of the study, it was determined that the middle-school students produced 277 metaphors about music lessons and 195 metaphors about music teachers. Through examination of the metaphors produced for each dimension in terms of their common features, the metaphors about music lessons were put into 13 different conceptual categories, and the metaphors about music teachers were put into 15 different conceptual categories.

Results of the study suggest that students consider music lessons as the most amusing and pleasing lesson among the others. The variation (36.46\%) in students' metaphors, which are produced to prove that music lessons are amusing and pleasing, and the levels of agreement $(57.41 \%)$ with these metaphors confirm that students experience music lessons especially with the amusing and pleasing aspects of it. Students consider music lessons to be the second $(10.08 \%)$ most purifying, relaxing and soothing lesson. For students, music lessons are like a guard saving them from the distresses of daily life, a soothing therapy center, a relaxing sleep and a house where they can find peace.

Results of our study suggest that students ( $\mathrm{f}=54,5.55 \%)$ perceive music lessons as a course which contains great learning opportunities enabling them to learn various songs and how to play various instruments. According to students $(\mathrm{f}=50,5.14 \%)$, music lessons teach, train and direct them. Music lessons provide information like an information center, source, riddle, puzzle, book or a cultural trip. They direct people like the moonlight, sun and the stars do. Music lessons can be regarded as a lesson of life. Music lessons make it possible to discover different worlds with different types of music and broaden points of view ( $f=18,1.85 \%)$. Music lessons are as necessary as fresh air, rain, food and so on $(\mathrm{f}=16,1.65 \%)$. Music lessons are a reflection of life and society. They enable us to give voice to our emotions ( $\mathrm{f}=10,1.03 \%$ ). Music lessons are like a bridge or road, which enable us to access the music $(\mathrm{f}=3,0.31 \%)$. Students can play instruments, sing songs and be active at all times $(\mathrm{f}=2,0.21 \%)$. 
The fact that the majority of the metaphors for music lessons is positive $(\mathrm{f}=844,86.83 \%)$ indicates how important music is in the lives of the students. However, as understood from the category, the duration of the music lessons is not long enough for the students $(\mathrm{f}=35,3.60 \%)$. The results of related studies indicate that students' metaphors do not highlight the insufficiency of the duration of other lessons (Ada, 2013; Çifçi, 2015; Mertol, Doğdu and Y1lar, 2013; Soysal and Afacan, 2012). Therefore, amendments for the duration of the music lessons should be made and the duration should be increased.

According to the results of this study, music lessons have been defined with negative specifications by certain students ( $\mathrm{f}=128,13.17 \%)$. Accordingly, certain students $(\mathrm{f}=87,8.95 \%)$ perceive music lessons as a complicated lesson, some ( $\mathrm{f}=10,1.03 \%)$ believe that ability is required to be successful in music lessons and some students $(\mathrm{f}=31,3.19 \%)$ state that music lessons have a negative teaching-learning atmosphere. If students feel they are in a teaching-learning atmosphere within which they think they will be more successful by making an effort and studying, this perception may be altered. Amendments, which will be made to the teaching-learning atmosphere considering this point, may transform students' success-oriented tendencies in music lessons from a performance-oriented tendency to a learning-oriented tendency.

The results of this study support the results of the studies of Ames and Archer (1988). In Ames and Archer's (1988) study, it was suggested that the students who perceived the importance of learning orientation within the classroom used more effective strategies, exhibited a more positive attitude towards the class, and had a stronger belief that success is achieved as a result of an effort displayed by a person. However, it was also found that the students, who perceived the performance goals as remarkable, tended to focus on their own skills by evaluating their own skills negatively and attributing failure to lack of skills. Church, Elliot and Gable's (2001) study results also clearly showed that perceived classroom environment affects the achievement goal orientation. In this context, music teachers have important responsibilities in regulating the perception of a negative learning-teaching environment in music lessons.

According to the study results, it was found that 14 of the categories 
created regarding the music teachers had positive characteristics and 1 had negative characteristics. According to these categories, most of the students ( $\mathrm{f}=934,96.09 \%)$ described their music teacher as a person who cares, who has an artistic personality, who is an information source, who is admired, who provides guidance, who entertains, who is loved, who is curative, who teaches, who gives color to life, who is valuable, who gives happiness, who makes you love music and who is original. However, in the study, it was found that 38 of the students (3.91\%) described their music teacher as a person who was not loved. This situation might be related to the perception of the personal characteristics of the music teacher.

\section{Conclusion}

In accordance with the study results, it can be seen that middle-school students creat many metaphors emphasizing various aspects of these concepts in describing their perceptions of music lessons and music teachers. Metaphors can be effective tools for music teachers to reveal the perceptions of their students on the lesson and recognize the perceptions of their students. Revealing this perception might help the teacher in implementing an internal evaluation and regulating the learning-teaching environment effectively. Researchers can develop scales to be used in determining the perceptions of music lessons and music teachers based on the categories created in this study. In addition, studies could be conducted to examine the relationships of the perceptions of music lessons and music teachers with various variables.

\section{Giriş}

Metafor, bir tür şeyi başka bir tür şeye göre anlamak ve tecrübe etmektir (Lakoff ve Johnson, 2005, s.27). Grekçe metaphoradan gelen metafor kelimesi, meta: öte ile pherein: taşımak, yüklenmek kelimelerinin birleşimidir ve bir yerden başka bir yere götürmek anlamındadır (Lakoff ve Johnson, 2005, s.13). Metaforlar, olayların oluşumu ve işleyişi hakkında düşünceleri yapılandıran, yönlendiren ve kontrol eden en güçlü zihinsel araçlardan biridir. Metaforlar, bireylerin kişisel tecrübelerine anlam vermeleri bakımından, aynı zamanda, "tecrübelerin dili" olarak da tanımlanmaktadır (Miller, 1987, akt; Saban, 2004, s.1). Metafor, genel olarak söylemi süslemeye yönelik söz sanatlarından biri olarak görülse de son yıllarda giderek insanın dünyayı kavrama veya görme biçimi olarak ele alınmaya başlamıştır (Morgan, 1998, akt; Asaman, 2013, s.20). Metaforlar, bir kavramı farklı bir kavramla tanımlama, 
bir kavramı farklı bir kavrama benzeterek betimleme, bir kavramı farklı bir boyutta görme ve yorumlama özellikleriyle (Tompkins ve Lawley, 2002, akt; Girmen, 2007, s.26) araştırmalarda bir veri toplama aracı olarak kullanılmıştır. Metaforlar, müzik alanındaki araştırmalarda da bir veri toplama aracı olarak yerini almıştır.

Aydıner-Uygun'a göre (2015), müzik alanyazınında metaforun bir veri toplama aracı olarak kullanıldığı çalışmalar üç tipte karşımıza çıkar. Buna göre bir grup çalışmada metafordan sözlü-sözsüz müzik eserlerindeki anlatımın analizinde bir araç olarak faydalanılmakta; bir grup çalışmada da metaforun müziksel ifadenin oluşturulması ve geliştirilmesinde bir öğretim aracı olarak etkisi sınanmaktadır. Bir grup çalışmada ise metafor, müzik alanındaki kavramlara ilişkin algıların belirlenmesinde temel bir veri toplama aracı işlevindedir. Ulusal müzik alanyazını incelendiğinde bu çerçevedeki çalışma örneklerine son beş yılda ağırlık verildiği gözlenmektedir. Bu çalışmalardan Özkul'un çalışmasında (2013) müzik-dil ilişkisi odağında müziksel anlatımdaki metaforlar ele alınırken, Mustan-Dönmez ve Karaburun'un çalışmalarında (2013), türkü sözlerinde yer alan metaforik anlatım geleneği incelenmiştir. Koca'nın çalışmasında (2012), okul öncesi öğretmen adaylarının müzik öğrenmeye ilişkin algılarının metaforlar yoluyla ortaya çıkarılması amaçlanmıştır. Umuzdaş ve Umuzdaş'ın çalışmalarında (2013), sınıf öğretmeni adaylarının müzik dersine ilişkin algıları metaforlar aracılığıyla analiz edilmiştir. Babacan'ın çalışmasında (2014) güzel sanatlar lisesinde öğrenim gören öğrencilerin, Mentiş-Köksoy'un çalışmasında da (2015) sınıf öğretmenliği öğrencilerinin müzik kavramına ilişkin algıları metaforlar aracılığıyla belirlenmiş̧ir. Dinç-Altun'un çalışmasında (2014), müzik öğretmenliği öğrencilerinin piyano dersine ilişkin algılarının metaforik analizi yapılmıştır. Aydıner-Uygun'un (2015) çalışmasında da, öğretmen adaylarının geleneksel müzik türlerine ilişkin algıları metaforlar aracılığıyla tespit edilmiştir.

Metafor bir düşünme biçimi (Morgan, 1997, akt; Akkaya, 2012, s.33) ve bir alg1 arac1 (Arnett, 1999, akt; Akkaya, 2012, s.33) olması bakımından, eğitim alanlarındaki pek çok sorunun belirlenmesinde bir araç olarak kullanılabilir (Akkaya, 2012, s.33). Eğitim alanlarındaki sorunların tespit edilmesi, ilgili alanın niteliğine ilişkin tedbirlerin alınmasını ve böylece öğrencilerin daha iyi bir şekilde yetiştirilmelerini sağlayabilir. Bu noktada dersle ve öğretmenle ilgili algıların bilinmesi, eğitim alanındaki sorunların kaynağına 
inilmesine katkıda bulunabilir. Metaforlar, öğrencilerin derse ve öğretmene ilişkin soyut olan algılarının somut olan kavramlarla yer değiştirilerek daha iyi bir şekilde açıklanmasına aracı olabilir. Nitekim ilgili çalışmalar incelendiğinde çeşitli derslere ilişkin algıların metaforlar aracılığıyla analiz edildiği çalışmalara (Çifçi, 2015; Demirci-Güler, 2012; Dinç-Altun, 2014; Duman11-Kadızade, 2014; Mertol, Doğdu ve Yılar, 2013; Mete, 2013; Umuzdaş ve Umuzdaş, 2013) rastlanmaktadır. Ayrıca öğretmenle ilgili algıların metaforlar aracılığıyla analiz edildiği çalışmalar da (Afacan, 2011; Bahar-Güner, Tunca, Alkın-Şahin ve Oğuz, 2015; Cerit, 2008; Çulha-Özbaş, 2012; Çulha-Özbaş ve Aktekin, 2013; Ekiz ve Koçyiğit, 2013; Eminoğlu-Küçüktepe ve Gürültü, 2014; Kalyoncu, 2012; Koç, 2014; Oflaz, 2011; Saban, 2004, 2011; Şengül, Katranc1 ve Gerez-Cantimer, 2014; Wells-Yalçın, 2015; Zeren, 2015) mevcuttur. Bazı çalışmalarda da hem ders hem de o dersin öğretmenine ilişkin algıların metaforlar yoluyla analiz edildiği (Ada, 2013; Akça-Berk, Gültekin ve Çençen, 2015; Soysal ve Afacan, 2012) görülmektedir. Bu çalışmalar içerisinden ortaokul öğrencilerinin örneklem alındığı çalışmaların (Ada, 2013; Cerit, 2008; Çifçi, 2015; Mertol, Doğdu ve Y1lar, 2013; Oflaz, 2011; Şengül, Katrancı ve Gerez-Cantimer, 2014) son yıllarda artış gösterdiği fark edilmektedir. Ancak müzik alanındaki çalışmalar içerisinde ortaokul öğrencilerinin örneklem alınarak müzik dersi ve müzik öğretmenine ilişkin algılarının metaforlar aracılığıyla analiz edildiği herhangi bir çalışmaya rastlanmamıştır. Bu bakımdan bu çalışmada ortaokul öğrencilerinin müzik dersi ve müzik öğretmenine ilişkin algılarının metaforlar yoluyla ortaya çıkarılabileceği düşünülmüştür.

Ortaokullarda müzik dersleri, öğrencinin müziksel dinleme, söyleme, çalma, üretme yoluyla müziksel kültürlenmesi, müzik beğenisinin oluşmas1-gelişmesi ve müziğe yönelmesinde etkin işlevlere sahiptir. Müzik dersinin bu işlevlerini yerine getirmesinde öğrencinin müzik dersi ve müzik öğretmenine ilişkin algılarının belirlenmesi önem taşımaktadır. Bu algının belirlenmesinde "metafor" öğrencilerin soyut olan kavramları somut olarak ifade etmelerini sağlayarak, düşünme ve görme biçimlerinin açılanmasına aracı olabilir. Müzik dersine ilişkin algıların belirlenmesiyle dersin öğretme-öğrenme ortamı, işılenişi ile kazanımlarına ilişkin ipuçlarının yakalanarak dersin öğrencinin yaşantısındaki yeri açıklanabilir. Müzik öğretmenine ilişkin algıların belirlenmesiyle de müzik öğretmeninin sahip olduğu ya da sahip olması beklenen nitelikleri öğrencinin gözünden görülebilir. 
Buraya kadar bahsedilenlere dayalı olarak bu çalışmanın amacı, ortaokul öğrencilerinin müzik dersi ve müzik öğretmenine ilişkin algılarının metaforlar yoluyla analiz edilmesidir. Çalışmada bu amaç doğrultusunda şu soruların cevapları aranmışıı:

a. Ortaokul öğrencilerinin müzik dersine ilişkin sahip oldukları metaforlar nelerdir?

b. Ortaokul öğrencilerinin müzik öğretmenine ilişkin sahip oldukları metaforlar nelerdir?

c. Müzik dersine ilişkin ortaya çıkan metaforlar ortak özellikleri bak1mından hangi kavramsal kategoriler altında toplanabilir?

d. Müzik öğretmenine ilişkin ortaya çıkan metaforlar ortak özellikleri bakımından hangi kavramsal kategoriler altında toplanabilir?

\section{Yöntem}

$\mathrm{Bu}$ bölümde çalışmanın deseni ile çalışma grubu hakkında bilgiler verilmekte, verilerin toplanması ve analizinde izlenen yollar açıklanmaktadır.

\section{Çalışmanın Deseni}

$\mathrm{Bu}$ çalışma, karma araştırma türündedir. Karma araştırmada, nicel ve nitel yöntemler ya da nicel ve nitel paradigma karakteristikleri karma olarak yer alır (Balcı, 2015, s.44). Bu çalışmada karma modelle ortaokul öğrencilerinin müzik dersi ve müzik öğretmeni algılarına ilişkin elde edilen nitel veriler, tekrarlanma sıklıkları hesaplanarak nicel verilere dönüştürülmüştür.

\section{Çalışma Grubu}

$\mathrm{Bu}$ araştırmanın çalışma grubunu Niğde ili merkez ilçede yer alan 12 ortaokuldan küme örnekleme yöntemi ile seçilen 6 ortaokulun 5, 6, 7 ve 8 . sınıflarında öğrenim görmekte olan öğrenciler oluşturmaktadır. Bu ortaokullar alfabetik sira ile Alparslan, Atatürk, Kanunî Sultan Süleyman, Kemâl Aydoğan, Mevlâna ve 23 Nisan Havacılar Ortaokulları'dır. Çalışma grubunu 2014-2015 eğitim-öğretim yılında bu ortaokullarda öğrenim görmekte olan 972 öğrenci oluşturmuştur. Çalışma grubu öğrencilerinin \%25.72'si ( $\mathrm{N}=250)$ 5.sinif, \%23.97'si ( $\mathrm{N}=233$ ) 6.sinif, \%24.89'u ( $\mathrm{N}=242)$ 7.sinif ve \%25.41'i ( $\mathrm{N}=247)$ 8. sinıfta öğrenim görmektedir. 


\section{Verilerin Toplanması}

$\mathrm{Bu}$ çalışmanın verileri, ortaokul öğrencilerinin müzik dersi ve müzik öğretmenine ilişkin sahip oldukları algıları ortaya koymak amacıyla "Müzik dersi ... gibidir. Çünkü ..." ve "Müzik öğretmeni ... gibidir. Çünkü ..." ifadelerini tamamlamaları istenen bir form aracıllğıyla elde edilmiştir. $\mathrm{Bu}$ form, araştırmacılar tarafından okullara bizzat gidilerek ve her bir sınıfa veri toplama aracıyla ilgili açıklamalar yapılarak uygulanmıştır. Bu formda "gibi" kavramı metaforun konusu ile kaynağı arasındaki bağın kurulmasına yardımcı olmak için kullanılmıştır. "Çünkü” kavramıyla da çalışma grubu öğrencilerinin ürettikleri metaforlara mantıksal bir dayanak oluşturmaları sağlanmaya çalışılmıştır.

\section{Verilerin Analiz Edilmesi}

$\mathrm{Bu}$ çalışmadan elde edilen verilerin analizinde, içerik analizi yöntemi kullanılmıştır. İçerik analizinde amaç, toplanan verileri açıklayabilecek kavramlara ve ilişkilere ulaşmaktır. İçerik analizinde temelde yapılan işlem, birbirine benzeyen verileri belirli kavramlar ve temalar çerçevesinde bir araya getirmek ve bunları okuyucunun anlayabileceği bir biçimde düzenleyerek yorumlamaktır (Yıldırım ve Şimşek, 2006, s.227). Betimsel analizde özetlenen ve yorumlanan veriler, içerik analizinde daha derin bir işleme tabi tutulur. Böylece betimsel bir yaklaşımla fark edilemeyen kavram ve temalar bu analiz sonucu keşfedilebilir. Bu çalışmada da içerik analizi yoluyla betimsel bir yaklaşımla fark edilemeyebilecek temaların bulunması amaçlanmıştır.

$\mathrm{Bu}$ çalışmanın verileri beş aşamada analiz edilmiştir. $\mathrm{Bu}$ aşamalar: geçerli metaforların kodlanması ve geçersiz metaforların ayıklanması aşaması, örnek metafor ifadelerinin derlenme aşaması, temaların bulunması ve temalara göre kategori geliştirme aşaması, geçerlik ve güvenirliği sağlama aşaması ve nitel verilerin nicel verilere dönüştürülerek SPSS programı arac1lığıyla analiz edilme aşamasıdır. Aşağıda bu aşamalar ayrı ayrı ele alınarak açıklanmaktadır.

\section{Geçerli metaforların kodlanması ve geçersiz metaforların ayıklanması aşaması}

Çalışma kapsamında ortaokul öğrencilerinin ürettikleri metaforlara ilişkin veriler, ilk aşamada geçerli olup olmama durumlarına göre ayıklan- 
mıştır. Bu ayıklama sonucunda 972 öğrencinin metaforlarının geçerli olduğu tespit edilmiştir. Sonraki aşamada her kavram altında yer alan metaforlar, öğrencilerin ifadeleri 1şığında kodlanmıştır (Örneğin: müzik dersine ilişkin metaforlar "eğlence merkezi”, "yabancı dil”; müzik öğretmenine ilişkin metaforlar "melek", "sanatçı"... vb.). Bu aşamada geçerli metaforlar alfabetik olarak sıralanırken, geçersiz metaforlar içeren (benzetilen kavramla benzerlik nedeni uyuşmayan metaforlar içeren) kâğıtlar $(\mathrm{n}=125)$ ile boş bırakılan kâğıtlar (n=132) ayıklanmıştır. Böylece çalışmanın başlangıcında 1229 öğrenciden oluşacağı öngörülen çalışma grubu, geçersiz kâğıtların ayıklanmasıyla 972 öğrenciden oluşmuştur.

\section{Örnek metafor ifadelerinin derlenme aşaması}

Bu aşamada, çalışma grubu öğrencilerinin geçersiz kağıtları veri analizi dışında tutularak 972 geçerli kâğıt üzerinde örnek metafor ifadelerinin derlenmesine başlanmıştır. Bu derlemenin yapılabilmesi için öğrencilerin ürettikleri metaforlar yeniden incelenmiş ve metaforu en iyi açıkladığ düşünülen ifadelerden örnek metafor ifadeleri seçilmiştir. Bu ifadelerin kim tarafindan üretildiğine ilişkin kişisel bilgiler, örnek ifadenin yanına parantez içinde okul adı, sınıf ve cinsiyet kodlanarak verilmiştir. Parantez içinde yer alan Alparslan, Atatürk, Kanunî Sultan Süleyman vb. ifadeler okul adlarını, 5, 6, 7, 8 rakamları sınıf düzeyini, K ve E harfleri de cinsiyeti belirtmektedir.

\section{Temaların bulunması ve temalara göre kategori geliştirme}

\section{aşaması}

$\mathrm{Bu}$ aşamada çalışma grubu öğrencilerinin müzik dersi ve müzik öğretmenine ilişkin ürettikleri metaforlar ortak özellikleri bakımından incelenmiştir. $\mathrm{Bu}$ amaçla metaforlar, benzerlik kurulan kavram, durum, nesne, olay vb. ile bu kavram, durum, nesne, olay vb. arasındaki ilişkiler bakımından analiz edilerek temalar oluşturulmuş ve bu temalara göre kategoriler geliştirilmiştir. Bu inceleme sonucunda 'müzik dersi' için toplam 13 ve 'müzik öğretmeni' için toplam 15 farklı kavramsal kategori oluşturulmuştur.

Tablo 1'de, müzik dersine ilişkin kategori geliştirme aşamasında derlenen 277 adet metaforun belli bir kategori altında toplanmasında kullanılan özelliklere yer verilmektedir. 
Tablo 1. Müzik Dersine İlişkin 13 Kavramsal Kategori ve Bu Kategorileri Temsil Eden Özellikler

\begin{tabular}{ll}
\hline $\begin{array}{l}\text { 1. Ë̆lendiren ve mutluluk veren bir ders } \\
\text { olarak müzik dersi }\end{array}$ & $\begin{array}{l}\text { 2. Arındıran, dinlendiren ve huzur veren bir } \\
\text { ders olarak müzik dersi }\end{array}$ \\
- Müzik dersi, haftanın eğlencesidir. & - Müzik dersi, sıkıntıları unutturur. \\
- Müzik dersi, çalarak-söyleyerek eğlen- & - Müzik dersi, dinlendirir ve huzur verir. \\
dirir. &
\end{tabular}

3. Karmaşık bir ders olarak müzik dersi

- Müzik dersinde, başarılı olmanın yolu müziğin alfabesini bilmekten geçer.

- Müzik dersi, anlaşılması güç karmaşık bir derstir.

5. Öğretici ve yönlendirici bir ders olarak müzik dersi

- Müzik dersi, öğretici bir derstir.

- Müzik dersi, yetenekleri geliştirir.

7. Olumsuz ögrrenme algısının oluştuğu bir ders olarak müzik dersi

- Müzik dersi, sınav kaygısı oluşturur.

- Müzik dersi, sıkıcı bir derstir.
4. Zengin öğrenme durumlarını içeren bir ders olarak müzik dersi

- Müzik dersi, farklı şarkıların öğrenilmesini, farklı çalgıların tanınmasını ve çeşitli müzik bilgilerinin öğrenilmesini sağlar.

- Müzik dersi, yeteneklerin keşfedilmesini sağlar.

6. Bitmesi istenmeyen bir ders olarak müzik dersi

- Müzik dersi, çabucak bitmektedir.

- Müzik dersine ayrılan süre yetersizdir.

8. Bakış açısını zenginleştiren bir ders olarak müzik dersi

- Müzik dersi, farklı dünyalara götürür.

- Müzik dersi, müziksel kültürlenmeyi sağlar.

10. Başarinin yeteneğe dayalı olduğu bir ders olarak müzik dersi

- Müzik dersi, yetenekli olanların başarabileceği bir derstir.

- Müzik dersinde yetenek ölçüsünde başarılı olunabilir.

12. Müzikle buluşma noktası olarak müzik dersi

- Müzik dersi, müzikle buluşulan yerdir.

- Müzik dersi, toplumsal gerçekleri yansıtır.

- Müzik dersi, duygularımızın müzikle yansitıldığı bir derstir.
- Müzik dersi, müziğe ulaştıran köprüdür.

13. Öğrencinin aktif olduğu bir ders olarak müzik dersi

- Müzik dersi, etkinlikler yönünden zengindir.

- Müzik dersi, çalma ve söyleme ağırlıklıdır. 
Tablo 2'de, müzik öğretmenine ilişkin kategori geliştirme aşamasında derlenen 195 adet metaforun belli bir kategori altında toplanmasında kullanılan özellikler yer almaktadır.

Tablo 2. Müzik Öğretmenine İlişkin 15 Kavramsal Kategori ve Bu Kategorileri Temsil Eden Özellikler

1. Seven, güven veren ve koruyan bir kişi olarak müzik ögretmeni

-Müzik öğretmeni, şefkat yönüyle dikkat çeker.

- Müzik öğretmeni, güvenilen bir kişiliktir.

3. Hayranlık duyulan bir kişi olarak müzik ögretmeni

- Müzik öğretmeni, fiziksel ve kişisel özellikleri ile beğenilir.

- Müzik öğretmeni, mesleki özellikleri ile beğenilir.

5. Bilgi kaynă̆ı bir kişi olarak müzik öğretmeni

- Müzik öğretmeni, bilgisiyle ön plana çıkar.

- Müzik öğretmeni, müziksel repertuvara hâkimdir.

7. Sevilen bir kişi olarak müzik öğretmeni

- Müzik öğretmeni, sevecendir.

- Müzik öğretmeni, iyi kalplidir.

9. Şifa veren bir kişi olarak müzik öğretmeni

- Müzik öğretmeni, öğrencilerin sıkıntılarını paylaşır.

- Müzik öğretmeni, müziğiyle öğrencileri olumsuz düşüncelerden arındırır.

11. Hayata renk katan bir kişi olarak müzik ögretmeni

- Müzik öğretmeni, dersi renkli hale getirir.

- Müzik öğretmeni, hayata renk katar.
2. Sanatçı kişiliği ile müzik öğretmeni

- Müzik öğretmeni, yetenekli bir kişidir.

- Müzik öğretmeni, sesi güzel olan kişidir. 4. Eğlendirici yönü ile müzik öğretmeni

- Müzik öğretmeni, komik bir kişiliğe sahiptir.

- Müzik öğretmeni, çalarak söyleyerek eğlendirir.

6. Yol gösterici ve yönlendirici bir kişi olarak müzik ögrretmeni

- Müzik öğretmeni, müziğe giden yolu gösterir.

- Müzik öğretmeni, doğruya yönlendirir.

8. Sevilmeyen bir kişi olarak müzik öğretmeni

- Müzik öğretmeni, sinirli karakter yapısıyla tanınır.

- Müzik öğretmeni, öğrencileri tedirgin edecek davranışlar sergiler. 10. Öğretici yönü ile müzik ögretmeni

- Müzik öğretmeni, öğrencilere bilgi veren bir kişidir.

- Müzik öğretmeni, öğrencileri iyi yönde şekillendirir.

12. Değerli bir kişi olarak müzik ögretmeni

- Müzik öğretmeni, eşi benzeri olmayan bir kişidir.

- Müzik öğretmeni, paha biçilmez değerdedir. 
13. Mutluluk veren bir kişi olarak müzik ögretmeni

- Müzik öğretmeni, derste mutluluk saçan bir kişidir.

- Müzik öğretmeni, pozitif enerjisi ile öğrencilerin dersten mutlu ayrılmalarını sağlar.
14. Müziği sevdiren bir kişi olarak müzik ögretmeni

- Müzik öğretmeni, müziği sevdiren bir kişidir.

- Müzik öğretmeni, müziğin güzelliklerini aşılar.

15. Hayata orijinallik katan bir kişi olarak müzik öğretmeni

- Müzik öğretmeni, güldürürken düşündürür, düşündürürken öğretir.

- Müzik öğretmeni, yeni bilgiler verir.

\section{Geçerlik ve güvenirliği sağlama aşaması}

Bir çalışmada geçerliği sağlayabilmenin ön koşulu güvenirliği sağlamaktır (Karasar, 2013, s.148). Bu bakımdan çalışmada öncelikle güvenirlik sağlanmaya çalışılmıştır. Nitel veriye dayalı bu çalışmada güvenirlik için, ölçümler arasındaki tutarlılık elde edilmiştir. Nitekim Meriam'a (2013, s.212) göre "Nitel bir çalı̧̧manın tekrarlanması aynı sonuçları ortaya çıkarmayabilir. Ancak, bu herhangi bir çalışmanın değerini düşürmez, çünkü aynı veriler hakkında sayısız yorum yapılabilir. Burada nitel araştırmalar için asıl soru ulaşılan sonuçların toplanan verilerle ne kadar tutarlı olduğudur".

Çalışmanın güvenirliğini sağlama aşamasında, ortaokul öğrencilerinin müzik dersi ve müzik öğretmenine ilişkin ürettikleri metaforların hangi kategorilerle eşleşebileceği uzman görüşleri aracıllı̆ıyla belirlenmiştir. Bunun için öncelikle araştırmacılar tarafından alfabetik olarak sıraya dizilen metaforlar, ilgili oldukları düşünülen kategorilerin altına yazılmıştır. Uzman görüşlerinin alınması amacıyla çalışmanın her iki boyutuna ilişkin olarak üretilen metaforların listesini, oluşturulan kategorilerin isimlerini ve özelliklerini içeren bir form hazırlanmıştır. Uzmanlardan, öğrencilerin ürettikleri metaforları oluşturulan kategorilerin özelliklerine göre yerleştirmeleri istenmiştir. $\mathrm{Bu}$ yerleştirme sonucunda uzmanlardan elde edilen görüşler 1şığında kategoriler yeniden gözden geçirilmiştir.

Güvenirlik çalışması kapsamında görüşüne başvurulan uzmanlar, Ömer Halisdemir Üniversitesi'nde görev yapmakta olan bir müzik eğitimi (Doç. Dr. XX), bir ölçme-değerlendirme (Yrd. Doç. Dr. XX) ve bir Türk Dili (Yrd. Doç. Dr. XX) uzmanıdır. Araştırmacılar ve görüşlerine başvurulan uzmanlar, veri analizinin her aşamasında müzakere yoluna gitmişlerdir. Ve- 
riler üzerinde son işlem, Kalem Dergisi alan hakemlerinin görüşleri doğrultusunda yapılmıştır.

Çalışmada güvenirlik sağlandıktan sonra geçerliğin de sağlanmasına çalışılmıştır. Geçerlik ölçülmek istenenin başka şeylerle karıştırılmadan ölçülebilmesidir (Karasar, 2013, s.151). Bu çalışmada geçerliği sağlamak için müzik dersine ilişkin 13 kategorinin ve müzik öğretmenine ilişkin 15 kategorinin nasıl oluşturulduğu ayrıntılı olarak açıklanmıştır. Ayrıca her bir boyut için oluşturulan metaforlar içerisinden kategoriyi en iyi temsil ettiği düşünülen metafor ifadeleri seçilerek bulgular bölümünde verilmiştir.

\section{Nitel verilerin nicel verilere dönüştürülerek SPSS programı aracılığıyla analiz edilme aşaması}

Müzik dersi için toplam 277 metafor ve müzik öğretmeni için toplam 195 metaforun belirlenmesinden ve bu metaforların ait oldukları kategorilerin geliştirilmesinden sonra, veriler SPSS istatistik programına aktarılmıştır. Sonraki aşamada her bir kavrama ilişkin metaforlar ile kategorileri temsil eden öğrenci sayılarının frekans (f) ve yüzdeleri (\%) hesaplanarak tablolar halinde sunulmuştur.

\section{Bulgular}

Bu bölümde, çalışma grubunu oluşturan ortaokul öğrencilerinin müzik dersi ve müzik öğretmenine ilişkin ürettikleri metaforların, kavramsal kategorilere göre dağılımlarına yer verilmektedir. Metaforların kavramsal kategorilere göre dağılımları, tablolar halinde sunulmakta ve her bir kategorinin özellikleri, öğrenciler tarafından üretilen örnek metaforlarla desteklenerek açıklanmaktadır. Metaforların yanında yer alan parantez içi açıklamalarda da sırasıyla öğrencinin öğrenim gördüğü okul, sınıf ve cinsiyet düzeyine ilişkin bilgiler sunulmaktadır.

\section{Müzik Dersi Metaforlarına İlişkin Bulgular}

Tablo 3'te, çalışma grubu öğrencilerinin müzik dersine ilişkin ürettikleri metaforların kavramsal kategorilere göre dağılımlarına yer verilmektedir. 
Tablo 3. Müzik Dersine İlişkin Metaforların Kavramsal Kategorilere göre Dağılımları

\begin{tabular}{|c|c|c|c|}
\hline $\begin{array}{l}\text { Kategoriler } \\
(n=13)\end{array}$ & $\begin{array}{l}\text { Kategoriyi } \\
\text { oluşturan } \\
\text { ögrenci } \\
\text { (f=972, } \\
\% 100)\end{array}$ & Metaforlar $(\mathbf{n}=277)$ & $\begin{array}{l}\text { Metafor } \\
\text { sayısı } \\
(\mathbf{f}=277, \\
\% 100)\end{array}$ \\
\hline
\end{tabular}

Alışveriş yapmak 1, anahtar 1, armağan 2, arabayla gezmek 2, arkadaşımın evi 1, arkadaşımla gezmek 1, arkadaşımla vakit geçirmek 1, aşk 3, basketbol oynamak 1, bayram 3, bedava çerez 1 , bilgisayar oyunu 5 , bulutlara çıkmak 1 , can 1, çarpışan arabaya binmek 3, çikolata 8, çocuk parkı 3, dans etmek 3 , dart oynamak 1 , disko 8 , doğum günüm 1 , dondurma 1, dönme dolap 2, dürüm yemek 1, eğlence cenneti 1 , eğlence dersi 1 , eğlence merkezi 105 , eğlence parkı 1 , eğlence yeri 2 , eğlenceli aktivite 1 , facebook 1 , film izlemek 1 , fuar alan 1 , futbol 1 , futbol oynamak 1 , gece kulübü 2, güzel bir resim 1, güzel film 1, hafta sonu gezisi

1. Eğlendi-

ren ve

Mutluluk

Veren Bir \%57.41

Ders Olarak

Müzik Dersi

1, haftada bir açan çiçek 1, haftanın eğlencesi 3, harikalar diyarı 1 , hayatın neşesi 1 , hediye almak 1 , hikaye okumak 1, jelibon 1, kafa dağıtma dersi 3, kafa dağıtmak 1, kahkaha makinesi 1, kelebek 1, komedi 1, komedi dükkanı 1 , $\mathrm{f}=101$, $\% 36.46$ komedi filmi 10, konser 41, koro 2, kuzenlerimle buluşmak 1, küçük kardeşim 1, lunapark 102, motor sürmek 1, müzik çalar 1 , müzik kutusu 2 , oyun 75 , oyun park1 51 , oyun alan1 4 , oyun oynamak 7 , oyun tüneli 1 , oyuncak oynamak 1 , özlediğin birini görmek 1 , park 8 , parkta oynamak 3 , parti 16 , pamuk şeker 1 , piknik yapmak 1, playstation oynamak 1 , resim çizmek 1 , resim dersi 2 , resim yapmak 1 , sakızlı topitop 1, sarmaşık 1, salıncakta sallanmak 1, sevdiğim aktivite 1 , sevgi barınağ 2 , sevgi dersi 1 , sirk 1 , soba 1 , spor etkinliği 1, sosyal ağ 1 , şaka dükkanı 1, şeker 3, şeker yemek 1, şerbet 1 , şenlik 2, tatl 1, trambolin 1, uçak 1, uçan balon 2, uçmak 1, uçurtma uçurmak 1, yarışma 1, yolculuk yapmak 1, yüzmek 2

Cankurtaran 3, cennet 3, dinlendirici masaj 1, dinlenme

2.Arındıran,

Dinlendiren

ve Huzur $\mathrm{f}=98$,

Veren Bir \%10.08

Ders Olarak

Müzik Dersi odas 3 , dinlenme saati 3 , doğa manzaras 1 , elma ağacı 1 , evim 7 , huzur bahçesi 1 , kafa dinleme dersi 1 , kalp temizleyicisi 2, masaj koltuğu 3, masaj salonu 3, masal dinlemek 3, naneli şeker 2, orman 2, Prison Break 1, rahatlama terapisi 1 , sihirli değnek 1 , sihirli ders 1 , silgi 3 , sosyal $f=34$, $\% 12.27$ aktivite 1 , spor aktivitesi 1 , su sesi 1 , tatil 5 , tatil yapmak 4 , tedavi 2 , terapi 1 , terapi merkezi 28 , uyku 2, uyumak 4 , yatağım 1 , yeşil bir orman 1 , yoga 1 


\begin{tabular}{|c|c|c|c|}
\hline $\begin{array}{l}\text { 3.Karmaşık } \\
\text { Bir Ders } \\
\text { Olarak } \\
\text { Müzik Dersi }\end{array}$ & $\begin{array}{l}\mathrm{f}=87, \\
\% 8.95\end{array}$ & 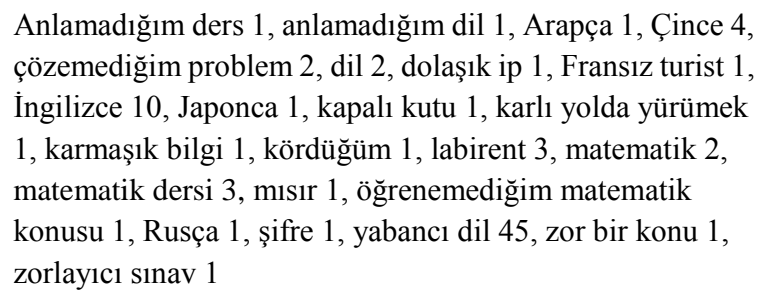 & $\begin{array}{l}\mathrm{f}=24, \\
\% 8.66\end{array}$ \\
\hline $\begin{array}{l}\text { 4.Zengin } \\
\text { Öğrenme } \\
\text { Durumlarını } \\
\text { İçeren Bir } \\
\text { Ders Olarak } \\
\text { Müzik Dersi }\end{array}$ & $\begin{array}{l}\mathrm{f}=54, \\
\% 5.55\end{array}$ & $\begin{array}{l}\text { Boya } 1 \text {, çiçek bahçesi } 9 \text {, dolma kalem } 1 \text {, gökkuşağ } 32 \text {, } \\
\text { gökyüzü } 1 \text {, gül bahçesi } 1 \text {, her renk dondurma } 1 \text {, konser } \\
\text { sahnesi } 1 \text {, müzik dünyası } 1 \text {, müzik kütüphanesi } 1 \text {, orkestra } \\
2 \text {, papağan } 1 \text {, sürpriz yumurta } 1 \text {, yetenekleri aydınlatan ders } \\
1\end{array}$ & $\begin{array}{l}\mathrm{f}=14, \\
\% 5.06\end{array}$ \\
\hline $\begin{array}{l}\text { 5.Öğretici ve } \\
\text { Yönlendirici } \\
\text { Bir Ders } \\
\text { Olarak } \\
\text { Müzik Dersi }\end{array}$ & $\begin{array}{l}\mathrm{f}=50, \\
\% 5.14\end{array}$ & $\begin{array}{l}\text { Ana dilim } 2 \text {, ay 1şı̆̆ } 1 \text {, bilgi dükkân } 12 \text {, bilgi kapıs } 1 \text {, bilgi } \\
\text { kaynağ } 2 \text {, bilgi kutusu } 1 \text {, bilmece } 1 \text {, bulmaca } 6 \text {, güneş } 7 \text {, } \\
\text { hayatın dersi } 1 \text {, kitap } 6 \text {, kitap okumak } 3 \text {, kültür gezisi } 1 \text {, } \\
\text { puzzle } 7 \text {, satranç oynamak } 1 \text {, tekerlek } 3 \text {, verimli toprak } 2 \text {, } \\
\text { yetenek öğrendiğin yer } 1 \text {, yıldız } 1 \text {, zekâ oyunu } 1\end{array}$ & $\begin{array}{l}\mathrm{f}=20, \\
\% 7.22\end{array}$ \\
\hline $\begin{array}{l}\text { 6. Bitmesi } \\
\text { İstenmeyen } \\
\text { Bir Ders } \\
\text { Olarak } \\
\text { Müzik Dersi }\end{array}$ & $\begin{array}{l}\mathrm{f}=35, \\
\% 3.60\end{array}$ & 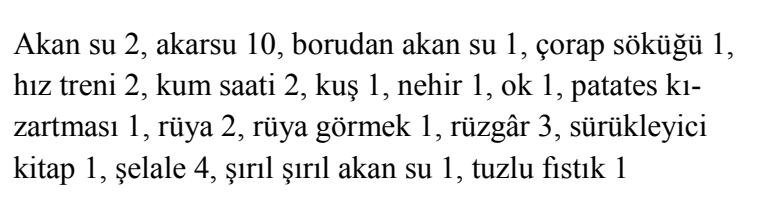 & $\begin{array}{l}\mathrm{f}=17, \\
\% 6.14\end{array}$ \\
\hline $\begin{array}{l}\text { 7. Olumsuz } \\
\text { Öğrenme } \\
\text { Ortamı } \\
\text { Algısının } \\
\text { Oluştuğu Bir } \\
\text { Ders Olarak } \\
\text { Müzik Dersi }\end{array}$ & $\begin{array}{l}\mathrm{f}=31, \\
\% 3.19\end{array}$ & $\begin{array}{l}\text { Açılmayan bilgisayar } 1 \text {, angarya iş } 1 \text {, bitmeyen ders } 1 \text {, boş } \\
\text { geçen ders } 1 \text {, boş oturmak } 1 \text {, çöplük } 1 \text {, dersin boş geçmesi } \\
1 \text {, elma kurdu } 1 \text {, hapishane } 1 \text {, içi boş oda } 1 \text {, işkence } 7 \text {, } \\
\text { kamikaze } 1 \text {, kaytarma dersi } 1 \text {, korku filmi } 2 \text {, korku tüneli } 1 \text {, } \\
\text { korkulu rüya } 1 \text {, meydan savaş1 } 1 \text {, ölüm } 1 \text {, önemsiz ders } 1 \text {, } \\
\text { sikıcı etkinlik } 2 \text {, sevmediğim ders } 2 \text {, sinek vizıltısı } 1\end{array}$ & $\begin{array}{l}\mathrm{f}=22, \\
\% 7.94\end{array}$ \\
\hline $\begin{array}{l}\text { 8. Bakış } \\
\text { Açısını } \\
\text { Zenginleşti- } \\
\text { ren Bir Ders } \\
\text { Olarak Müzik } \\
\text { Dersi }\end{array}$ & $\begin{array}{l}\mathrm{f}=18 \\
\% 1.85\end{array}$ & $\begin{array}{l}\text { Ak1l 1, başka bir dünya } 1 \text {, derin bir deniz } 1 \text {, farklı bir dünya } \\
2 \text {, gezi } 1 \text {, gözlük } 1 \text {, Google } 1 \text {, hava durumu } 2 \text {, hayal etmek } \\
2 \text {, lokomotif } 1 \text {, pembe gözlük } 1 \text {, pencere } 1 \text {, roket } 2 \text {, suya } \\
\text { dalmak } 1\end{array}$ & $\begin{array}{l}\mathrm{f}=14, \\
\% 5.06\end{array}$ \\
\hline
\end{tabular}




\begin{tabular}{|c|c|c|c|}
\hline $\begin{array}{l}\text { 9. Temel Bir } \\
\text { İhtiyaç } \\
\text { Olarak } \\
\text { Müzik Dersi }\end{array}$ & $\begin{array}{l}\mathrm{f}=16, \\
\% 1.65\end{array}$ & $\begin{array}{l}\text { Bina temeli 1, bizim bir yarımız } 1 \text {, çınar } 1 \text {, enerji } 1 \text {, hava } 1 \text {, } \\
\text { kalbim } 1 \text {, kıymetli eşyam } 1 \text {, montum } 1 \text {, oksijen } 1 \text {, temiz } \\
\text { hava } 2 \text {, teneffüs } 1 \text {, tuvalet } 1 \text {, yağmur } 2 \text {, yemek } 1\end{array}$ & $\begin{array}{l}\mathrm{f}=14, \\
\% 5.06\end{array}$ \\
\hline
\end{tabular}

10. Başar1-

nın

Yeteneğe $\mathrm{f}=10, \quad$ Alışveriş merkezi 1, enstrüman çalmak 3, keman çalmak 1, $\mathrm{f}=8$, Dayalı k1.03 kutbol oynaması 1, oynayamadığım oyun 1, şiir

Olduğu Bir \% $\quad$ ezberlemek 1, ucu bitmiş kalem 1, yemek yapmak 1 $\% 2.89$

Ders Olarak

Müzik Dersi

\begin{tabular}{llll}
\hline $\begin{array}{l}\text { 11. Yansitıc1 } \\
\text { Bir Ders }\end{array}$ & $\mathrm{f}=10$, & & $\mathrm{f}=4$, \\
Olarak & $\% 1.03$ & Ayna 2, melodi dili 1, tiyatro 4, tiyatro sahnesi 3 & $\% 1.44$ \\
Müzik Dersi & & & \\
\hline
\end{tabular}

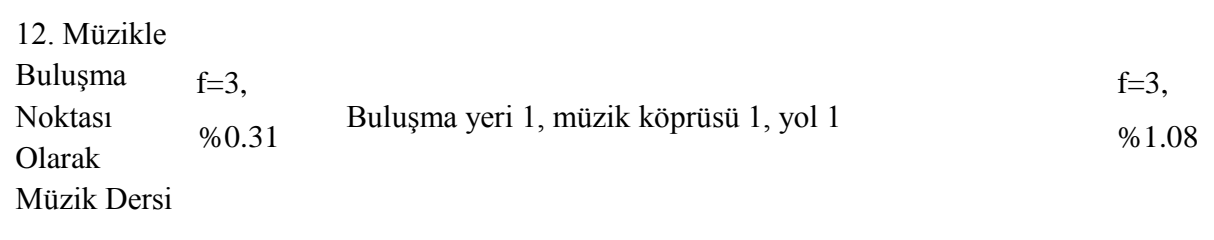

13. Öğrencinin Aktif Olduğu Bir Ders Olarak $f=2$, $\% 0.21$ Hacı yatmaz 1, sakız 1

$\mathrm{f}=2$, $\% 0.72$

Müzik Dersi

\section{Kategori 1. Eğlendiren ve mutluluk veren bir ders olarak müzik dersi}

Bu kategoriyi toplamda 558 (\%57.41) öğrenci ve 101 (\%36.46) metafor temsil etmektedir. Öğrenciler tarafindan en sık kullanılan metafor eğlence merkezidir $(\mathrm{f}=105)$. Bu metaforu lunapark $(\mathrm{f}=102)$ ve oyun $(\mathrm{f}=75)$ metaforlar1 takip etmektedir. Bu kategoriyi oluşturan metaforların öğrenciler tarafından en sık vurgulanan özelliğine göre müzik dersi, eğlendiren ve mutluluk veren bir derstir. Örneğin; "Müzik dersi eğlence merkezi gibidir. Çünkü eğlence merkezinde değişik oyunlar vardır. Hepsinde oynamak isterim ve çok eğlenirim. Müzik dersinde de değişik çalgllar var. Öğretmenimiz bize değişik şarkılar çallyor biz de söylüyoruz. Çok eğleniyoruz." (Mevlâna, 7, E). "Müzik dersi lunapark gibidir. Çünkü lunaparkta çok eğleniyorum. Müzik dersi de 
bence eğlenceli bir ders." (23 Nisan Havac1lar, 5, E). "Müzik dersi oyun gibidir. Çünkü eğlenceli geçer." (Alparslan, 6, E). "Müzik dersi aşk gibidir. Çünkü mutluluk verir." (Alparslan, 8, E). "Müzik dersi haftanın eğlencesi gibidir. Çünkü haftada bir de olsa müzik dersinde eğleniyoruz ve mutlu oluyorum. Ama çabuk bitiyor." (Atatürk, 8, K).

\section{Kategori 2. Arındıran, dinlendiren ve huzur veren bir ders olarak müzik dersi}

Bu kategoriyi toplamda 98 (\%10.08) öğrenci ve 34 (\%12.27) metafor temsil etmektedir. Öğrenciler tarafindan en stk kullanılan metafor terapi merkezidir $(\mathrm{f}=28)$. Bu metaforu evim $(\mathrm{f}=7)$, tatil $(\mathrm{f}=5)$, tatil yapmak $(\mathrm{f}=4)$ ve uyumak $(\mathrm{f}=4)$ metaforları takip etmektedir. Bu kategoriyi oluşturan metaforların öğrenciler tarafından vurgulanan özelliğine göre müzik dersi stres ve sıkıntıdan arındıran, insanı dinlendiren ve huzur veren bir derstir. Örneğin; "Müzik dersi terapi merkezi gibidir. Çünkü sıkıntılarımı unuturum ve rahatlarım." (23 Nisan Havacılar, 7, E). "Müzik dersi evim gibidir. Çünkü kendimi güvende hissederim. Rahatllk ve huzur verir." (Alparslan, 8, K). "Müzik dersi tatil gibidir. Çünkü dinlenirim." (Kemal Aydoğan, 6, K). "Müzik dersi uyumak gibidir. Çünkü uyumak vücudumu dinlendirir. Müzik dersi de ruhumu dinlendirir." (Mevlâna, 5, K).

\section{Kategori 3. Karmaşık bir ders olarak müzik dersi}

Bu kategoriyi toplamda 87 (\%8.95) öğrenci ve 24 (\%8.66) metafor temsil etmektedir. Öğrenciler tarafindan en sık kullanılan metafor yabanc1 dildir $(\mathrm{f}=45)$. Dersin farklı bir dili olduğuna vurgu yapan diğer metaforlar ise İngilizce ( $\mathrm{f}=10)$, Çince $(\mathrm{f}=4)$, dil $(\mathrm{f}=2)$, anlamadı̆̆ı̆m dil ( $\mathrm{f}=1)$, Arapça $(\mathrm{f}=1)$, Japonca ( $\mathrm{f}=1)$, Rusça ( $\mathrm{f}=1$ ) ve Fransız turisttir $(\mathrm{f}=1)$. Bu kategoriyi oluşturan metaforların öğrenciler tarafından en sık vurgulanan özelliğine göre müzik dersi, anlaşılması güç karmaşı bir derstir. Örneğin; "Müzik dersi yabancı dil gibidir. Çünkü değişik alfabesi olduğu için anlamakta zorlanıyorum. Notaları ögrenmek zor geliyor." (Kanunî Sultan Süleyman, 6, K). "Müzik dersi İngilizce gibidir. Çünkü anlamasını bilene kolay bilmeyene zor." (Mevlâna, 5, E). "Müzik dersi Çince gibidir. Çünkü notalar çok karışık. Bir türlü anlamıyorum." (Kanunî Sultan Süleyman, 5, E). "Müzik dersi çözemediğim problem gibidir. Çünkü yeteneğim yok yapamıyorum.” (Mevlâna, 7, E). 


\section{Kategori 4. Zengin öğrenme durumlarını içeren bir ders olarak müzik dersi}

$\mathrm{Bu}$ kategoriyi toplamda $54(\% 5.55)$ öğrenci ve 14 (\%5.06) metafor temsil etmektedir. Öğrenciler tarafından en sık kullanılan metafor gökkuşağıdır ( $\mathrm{f}=32$ ). Bu metaforu çiçek bahçesi ( $\mathrm{f}=9$ ) ve orkestra $(\mathrm{f}=2)$ metaforları takip etmektedir. Bu kategoriyi oluşturan metaforların öğrenciler tarafından vurgulanan özelliğine göre müzik dersi, öğrenme durumlarında çeşitliliğin fazlaca yer aldığı bir derstir. Örneğin; "Müzik dersi gökkuşağı gibidir. Çünkü gökkuşağında yedi renk vardır. Müzikte de yedi nota vardır. Yedi notayl farklı farklı bir araya getiririz. Değişik şarkılar söylemeyi ve çalmayı öğreniriz." (Atatürk, 8, K). "Müzik dersi çiçek bahçesi gibidir. Çünkü çiçek bahçesinde farklı renklerde çiçekler görürüz. Müzik dersinde de çeşit çeşit müzik aletlerini tanırız." (Atatürk, 8, K). "Müzik dersi orkestra gibidir. Çünkü orkestrada çok çeşitli çalgllar, çok çeşitli müzikleri uyum ve denge içerisinde çalar. Müzik dersinde de çok çeşitli müzikleri ve müzik bilgilerini dengeli bir şekilde ögreniriz." (Alparslan, 8, K).

\section{Kategori 5. Öğretici ve yönlendirici bir ders olarak müzik dersi}

$\mathrm{Bu}$ kategoriyi toplamda 50 (\%5.14) öğrenci ve 20 (\%7.22) metafor temsil etmektedir. Öğrenciler tarafından en sık kullanılan metaforlar güneş $(\mathrm{f}=7$ ) ve puzzle $(\mathrm{f}=7$ ) metaforlarıdır. $\mathrm{Bu}$ metaforu bulmaca $(\mathrm{f}=6)$ metaforu takip etmektedir. Bu kategoriyi oluşturan metaforların öğrenciler tarafından vurgulanan özelliğine göre müzik dersi, öğretici ve yönlendirici bir derstir. Örneğin; "Müzik dersi güneş gibidir. Çünkü ışık saçar, aydınlığıyla yol gösterir." (Alparslan, 8, E). "Müzik dersi puzzle gibidir. Çünkü hem öğretir hem eğitir.” (Kemal Aydoğan, 8, E). “Müzik dersi bulmaca gibidir. Çünkü öğretir ve yeteneğini geliştirir." (Atatürk, 7, K).

\section{Kategori 6. Bitmesi istenmeyen bir ders olarak müzik dersi}

$\mathrm{Bu}$ kategoriyi toplamda 35 (\%3.60) öğrenci ve 17 (\%6.14) metafor temsil etmektedir. Öğrenciler tarafından en sık kullanılan metafor akarsudur $(\mathrm{f}=10)$. Bu metaforu şelale ( $\mathrm{f}=4)$ ve rüzgâr $(\mathrm{f}=3)$ metaforları takip etmektedir. $\mathrm{Bu}$ kategoriyi oluşturan metaforların öğrenciler tarafindan vurgulanan özelliğine göre müzik dersine verilen süre yetersizdir. Örneğin; "Müzik dersi akarsu gibidir. Çünkü akarsu nasıl akıp gidiyorsa müzik dersi de çabuk geçer ve biter." (Kemal Aydoğan, 5, K). "Müzik dersi şelale gibidir. Çünkü şelale hızlı akar. Müzik dersi de hızlı geçer." (23 Nisan Havacılar, 6, K). "Müzik 
dersi rüzgâr gibidir. Çünkü rüzgâr gibi esip geçer. Ne zaman bittiğini anlayamam.” (23 Nisan Havacilar, 8, K).

\section{Kategori 7. Olumsuz öğrenme ortamı algısının oluştuğu bir ders olarak müzik dersi}

Bu kategoriyi toplamda 31 (\%3.19) öğrenci ve 22 (\%7.94) metafor temsil etmektedir. Öğrenciler tarafından en sık kullanılan metafor işkencedir $(\mathrm{f}=7)$. Bu metaforu korku filmi ( $\mathrm{f}=2$ ) ve sikıcı etkinlik ( $\mathrm{f}=2$ ) metaforları takip etmektedir. Bu kategoriyi oluşturan metaforların az sayıdaki öğrenci ( $\mathrm{f}=31$, \%3.19) tarafından vurgulanan özelliğine göre müzik dersi, olumsuz öğrenme ortamına sahiptir. Örneğin; "Müzik dersi işkence gibidir. Çünkü bitmek bilmiyor. Çok sıkllyyorum." (Kanunî Sultan Süleyman, 6, K). "Müzik dersi korku filmi gibidir. Çünkü her an sözlü olma korkusuyla elim ayağım titrer." (Mevlâna, 5, E). "Müzik dersi sıkıcı etkinlik gibidir. Çünkü müzik dersinde çok sıkılıyorum, ders zor geçiyor." (Kanunî Sultan Süleyman, 7, E).

\section{Kategori 8. Bakış açısını zenginleştiren bir ders olarak müzik dersi}

$\mathrm{Bu}$ kategoriyi toplamda 18 (\%1.85) öğrenci ve 14 (\%5.06) metafor temsil etmektedir. Öğrenciler tarafından en sık kullanılan metaforlar farklı bir dünya $(\mathrm{f}=2)$, hava durumu $(\mathrm{f}=2)$, hayal etmek $(\mathrm{f}=2)$ ve rokettir $(\mathrm{f}=2) . \mathrm{Bu}$ kategoriyi oluşturan metaforların öğrenciler tarafından vurgulanan özelliğine göre müzik dersi, bakış açısını zenginleştiren bir derstir. Örneğin; "Müzik dersi farklı bir dünya gibidir. Çünkü dinlediğimiz müziklerle farklı dünyalara gideriz." (Atatürk, 7, K). "Müzik dersi hava durumu gibidir. Çünkü hava durumu duygularımı etkiler, müzik dersi de müziklere bakış açımı etkiler." (Atatürk, 7, K). "Müzik dersi roket gibidir. Çünkü bizi dünyadan koparır ses âlemine götürür.” (Alparslan, 6, E).

\section{Kategori 9. Temel bir ihtiyaç olarak müzik dersi}

Bu kategoriyi toplamda 16 (\%1.65) öğrenci ve 14 (\%5.06) metafor temsil etmektedir. Öğrenciler tarafından en sık kullanılan metafor temiz hava $(\mathrm{f}=2)$ ve yağmurdur $(\mathrm{f}=2)$. Bu metaforları tuvalet $(\mathrm{f}=1)$ metaforu takip etmektedir. Bu kategoriyi oluşturan metaforların öğrenciler tarafından vurgulanan özelliğine göre müzik dersi, temel bir ihtiyaçtır. Örneğin; "Müzik dersi temiz hava gibidir. Çünkü yaşamımız için gereklidir.” (Mevlâna, 7, E). "Müzik dersi yağmur gibidir. Çünkü bitkilerin yaşaması için yağmur gereklidir. Bizim için de müzik dersi gereklidir." (Kemal Aydoğan, 5, E). "Müzik dersi tuvalet gibidir. Çünkü ihtiyaçlarımızı gidermemizi sağlar.” (Alparslan, 8, E). 


\section{Kategori 10. Başarının yeteneğe dayalı olduğu bir ders olarak müzik dersi}

$\mathrm{Bu}$ kategoriyi toplamda $10(\% 1.03)$ öğrenci ve $8(\% 2.89)$ metafor temsil etmektedir. Bu kategoriyi oluşturan metaforların öğrenciler tarafindan vurgulanan özelliğine göre müzik dersi, yetenekli olanların başarılı olabileceği bir derstir. Yeteneği olmayan öğrenciler, müzik dersini başaramama kaygısını yaşamaktadır. Örneğin; "Müzik dersi enstrüman çalmak gibidir. Çünkü yeteneği olmayan enstrüman çalamaz. Müzik dersini de yeteneği olmayan başaramaz." (Alparslan, 8, K). "Müzik dersi kızın futbol oynaması gibidir. Çünkü kız erkek kadar iyi futbol oynayamaz. Müzik dersinde de yeteneği olmayan başarll olamaz." (Atatürk, 7, E). "Müzik dersi alışveriş merkezi gibidir. Çünkü alışveriş merkezinde parası olanlar daha çok alı̧̧veriş yapar. Müzik dersinde de yeteneği olanlar başarılı olur." (Kemal Aydoğan, 7, E).

\section{Kategori 11. Yansitıcı bir ders olarak müzik dersi}

$\mathrm{Bu}$ kategoriyi toplamda 10 (\%1.03) öğrenci ve 4 (\%1.44) metafor temsil etmektedir. Öğrenciler tarafından en sık kullanılan metaforlar tiyatro $(\mathrm{f}=4)$ ve tiyatro sahnesidir $(\mathrm{f}=3)$. Bu metaforu ayna $(\mathrm{f}=2)$ ve melodi dili $(\mathrm{f}=1)$ metaforları takip etmektedir. Bu kategoriyi oluşturan metaforların öğrenciler tarafindan vurgulanan özelliğine göre müzik dersi, gerçekliği olan bir durumu yansıtır. Örneğin; "Müzik dersi tiyatro gibidir. Çünkü hayatı yansitır." (Atatürk, 8, K). "Müzik dersi ayna gibidir. Çünkü toplumların özelliklerini yansitan müzikler vardır ve gerçekleri gösterir." (Mevlâna, 8, E). "Müzik dersi melodi dili gibidir. Çünkü duygularımı müzikle anlatmayı ögretir." (Atatürk, $8, \mathrm{~K})$.

\section{Kategori 12. Müzikle buluşma noktası olarak müzik dersi}

Bu kategoriyi toplamda $3(\% 0.31)$ öğrenci ve 3 (\%1.08) metafor temsil etmektedir. Öğrenciler tarafından kullanılan metaforlar buluşma yeri ( $\mathrm{f}=1)$, müzik köprüsü $(\mathrm{f}=1)$ ve yol $(\mathrm{f}=1)$ metaforlarıdır. $\mathrm{Bu}$ kategoriyi oluşturan metaforların öğrenciler tarafindan vurgulanan özelliğine göre müzik dersi, müzikle buluşma noktasıdır. Örneğin; "Müzik dersi buluşma yeri gibidir. Çünkü notalarl ve flüt çalmayı öğrenmek için müzik dersinde buluşuyoruz." (23 Nisan Havacılar, 5, K). “Müzik dersi müzik köprüsü gibidir. Çünkü benim müzikle buluşmamı sağlar.” (Alparslan, 7, K). “Müzik dersi yol gibidir. Çünkü 
bizi müziğe götürür. Illerledikçe müziğin farklılıklarını keşfederiz." (Alparslan, 6, E).

\section{Kategori 13. Öğrencinin aktif olduğu bir ders olarak müzik dersi}

Bu kategoriyi toplamda $2(\% 0.21)$ öğrenci ve $2(\% 0.72)$ metafor temsil etmektedir. Öğrenciler tarafından kullanılan metaforlar hacıyatmaz $(\mathrm{f}=1)$ ve sakızdır ( $\mathrm{f}=1)$. Bu kategoriyi oluşturan metaforların öğrenciler tarafından vurgulanan özelliğine göre müzik dersi, sürekli aktif olunan bir derstir. Örneğin; "Müzik dersi hacıyatmaz gibidir. Çünkü hacıyatmaz hep ayakta durur. Hiç eğilmez. Biz de müzik dersinde sürekli flüt çallyoruz, şark söylüyoruz." (Kemal Aydoğan, 6, K). "Müzik dersi sakız gibidir. Çünkü sakız çiğnerken çenemiz durmaz. Müzik dersinde de biz hiç durmayız. Çalarız söyleriz." (Mevlâna, 5, K).

\section{Müzik Öğretmeni Metaforlarına İlişkin Bulgular}

Tablo 4'te, çalışma grubu öğrencilerinin müzik öğretmenine ilişkin ürettikleri metaforların kavramsal kategorilere göre dağılımlarına yer verilmektedir.

Tablo 4. Müzik Öğretmenine İlişkin Metaforların Kavramsal Kategorilere Göre Dağılımları

\begin{tabular}{|c|c|c|c|}
\hline $\begin{array}{l}\text { Kategoriler } \\
(n=15)\end{array}$ & $\begin{array}{l}\text { Kategoriyi } \\
\text { oluşturan } \\
\text { öğrenci } \\
\text { (f=972, } \\
\% 100)\end{array}$ & Metaforlar $(n=195)$ & $\begin{array}{l}\text { Metafor } \\
(\mathbf{f}=195, \\
\% 100)\end{array}$ \\
\hline $\begin{array}{l}\text { 1.Seven, } \\
\text { güven veren } \\
\text { ve koruyan } \\
\text { bir kişi } \\
\text { olarak } \\
\text { müzik } \\
\text { öğretmeni }\end{array}$ & $\begin{array}{l}\mathrm{f}=246, \\
\% 25.31\end{array}$ & $\begin{array}{l}\text { Abim } 1 \text {, anne } 54 \text {, arkadaş } 2 \text {, baba } 38 \text {, cankurtaran } 2 \text {, } \\
\text { dost } 3 \text {, huzurun anahtarı } 1 \text {, iyilik meleği } 1 \text {, melek } \\
135 \text {, pamuk } 4 \text {, sevgi küpü } 1 \text {, sırdaş } 3 \text {, uyarıcı melek } \\
1\end{array}$ & $\begin{array}{l}f=13, \\
\% 6.67\end{array}$ \\
\hline $\begin{array}{l}\text { 2. Sanatçi } \\
\text { kişiliği ile } \\
\text { müzik } \\
\text { öğretmeni }\end{array}$ & $\begin{array}{l}\mathrm{f}=224, \\
\% 23.04\end{array}$ & $\begin{array}{l}\text { Ağustos böceği } 1 \text {, aslan } 1 \text {, bülbül } 105 \text {, çalg1 } 1 \text {, kor- } \\
\text { no } 1 \text {, kanarya } 1 \text {, keman } 1 \text {, muhabbet kuşu } 1 \text {, mü- } \\
\text { zisyen } 2 \text {, müzik sanatçıs } 1 \text {, operac1 } 2 \text {, ressam } 1 \text {, } \\
\text { sanatç1 } 47 \text {, ses tellerinin kral1 } 1 \text {, solist } 1 \text {, şair } 1 \text {, } \\
\text { şarkıc1 } 56\end{array}$ & $\begin{array}{l}\mathrm{f}=17, \\
\% 8.72\end{array}$ \\
\hline
\end{tabular}




$\begin{array}{lllll}\text { 3. Hayran- } & & \begin{array}{l}\text { Adriana Lima 1, büyücü 1, çiçek 34, el sihirbazı 1, } \\ \text { film yıldızı 1, gül 11, idol 2, James Bond 1, karınca }\end{array} & \\ \begin{array}{l}\text { lik duyulan } \\ \text { bir kişi }\end{array} & \mathrm{f}=96, & \begin{array}{l}\text { 1, kahraman 1, kahramanım 3, kar tanesi 1, kraliçe } \\ \text { olarak }\end{array} & \text { f=23, } \\ \text { müzik } & & \begin{array}{l}\text { 1, kuğu 2, lale 1, manken 3, masal perisi 2, mıknatıs } \\ \text { 2, pamuk prenses 1, papatya 2, peri 3, prenses 18, }\end{array} & \% \\ \text { öğretmeni } & & & \\ & \text { sihirbaz 3 }\end{array}$

$\begin{array}{llll}\begin{array}{l}\text { 4. Eğlendi- } \\ \text { rici yönü ile }\end{array} & \mathrm{f}=95, & \begin{array}{l}\text { Canlı müzik programı 1, eğlence makinesi 1, ko- } \\ \text { medyen 54, lunaparktaki gondol 1, müzik çalar 9, }\end{array} & \mathrm{f}=10, \\ \begin{array}{l}\text { müzik } \\ \text { öğretmeni }\end{array} & \% 9.77 & \begin{array}{l}\text { müzik kutusu 10, palyaço 11, stendapçı 6, tiyatro } \\ \text { sanatçıs1 1, tiyatrocu 1 }\end{array} & \% 5.13\end{array}$

Ak1l kutusu 1, akıl küpü 1, ansiklopedi 3, ar1 2, ayaklı enstrüman 1, ayaklı kitap 1, bilgisayar 1, bilge kişi 1, bilgi dükkanı 1, bilgi hazinesi 1, bilgi

5. Bilgi kaynağı bir kişi olarak müzik öğretmeni kapısı 1, bilgi kutusu 3, bilgi küpü 1, bilgin 3, çok bilmiş amca 1, dâhi 1, dolup taşan nehir 1, filozof 1 , $\mathrm{f}=36$, gökyüzü 2, hayat bilgini 2 , hayat öğretmeni 1 , kaşif 1, kitap 14, kitaplık 1, mum 1, müzik ansiklopedisi 1, müzik bilgini 1, müzik dâhisi 7, müzik kitabı 7 , müzik sözlüğü 3 , müzik ustası 2 , profesör 2 , radyo 8 , sözlük 1 , verimli toprak 3 , zeka küpü 2
6. Yol gösterici ve yönlendirici $\mathrm{f}=79$, bir kişi olarak $\% 8.13$

müzik öğretmeni
Akort aleti 1, ampul 1, antrenör 1, ay 1, ayaklarım 1 , çalar saat 1 , çevirmen 1 , güneş 15 , 1şık 7 , kılavuz 4 , koro şefi 1, müzik lambası 1, müzik yoldaşı 2 , nehir yatağ 1 , orkestra şefi 1 , önder 1 , pusula 10 , rehber 11, ruh rehberi 1 , sol anahtarı 1, şimşek 1 , $\mathrm{f}=27$, $\% 13.85$ tercüman 2, trafik levhası 1, usta 5, yaşam koçu 1, yön levhası 2, yıldız 4

$\begin{array}{ll}\begin{array}{l}\text { 7. Sevilen } \\ \text { bir kişi }\end{array} & \mathrm{f}=48, \\ \text { olarak } & \% 4.94 \\ \text { müzik } & \\ \text { öğretmeni } & \end{array}$

Adamın dibi 2, adamın has1 1, ananas 2, bal 1, bal kaymak 1, çikolata 3, çikolatalı pasta 2 , çilek 1 , kalorifer 1, kankam 1, karpuz 2, kavun 1, limonata 1 , meyve 1 , muz 1 , nar 1 , pamuk şeker 12 , soba 1 , $\mathrm{f}=20$, $\% 10.26$ şeker 12, yorgan 1 
8. Sevilmeyen bir kişi olarak müzik öğretmeni
Angry Bird 1, bomba 3, bozuk plak 1, buzdolab1 1, dikenli gül 1, düşman 1 , elektrik süpürgesi 1 , iş$\mathrm{f}=17$, $\% 8.72$ kence aleti 1, karga 1, kaya 1, kutu kola 2, papağan 10 , taramalı tüfek 1 , torpil 1 , ütü 10 , vampir 1 , yanardă̆ 1

9. Şifa

veren bir

kişi olarak müzik $\mathrm{f}=23$, Çamaşır makinası 6, çöpçü 1, doktor 2, psikolog 6,

$\mathrm{f}=5$,

öğretmeni $\% 2.37$ terapist 8

$\% 2.56$

10. Öğretici yönü ile $\mathrm{f}=14$,

Aşç1 1, bahçıvan 2, büyütücü iksir 1, heykeltıraş 1,

$\mathrm{f}=8$, müzik $\% 1.44$ kalem 1 , marangoz 1 , meyve veren ağaç 6 , tebeşir 1 $\% 4.10$

öğretmeni

11. Hayata

renk katan bir $\mathrm{f}=8$,

kişi olarak

müzik

$\% 0.82$

Çiçek bahçesi 1, gökkuşağ 1, ilkbahar 1, kalem

$\mathrm{f}=6$,

öğretmeni

\begin{tabular}{|c|c|c|c|}
\hline $\begin{array}{l}\text { 12.Değerli } \\
\text { bir kişi olarak } \\
\text { müzik öğ- } \\
\text { retmeni }\end{array}$ & $\begin{array}{l}\mathrm{f}=6 \\
\% 0.62\end{array}$ & Başımın tacı 1 , mücevher 4 , pırlanta 1 & $\begin{array}{l}\mathrm{f}=3, \\
\% 1.54\end{array}$ \\
\hline $\begin{array}{l}\text { 13. Mutluluk } \\
\text { veren bir kişi } \\
\text { olarak müzik } \\
\text { öğretmeni }\end{array}$ & $\begin{array}{l}\mathrm{f}=5, \\
\% 0.51\end{array}$ & $\begin{array}{l}\text { Dizi sezon finali } 1 \text {, haciyatmaz } 1 \text {, pozitif elektron } 1 \text {, } \\
\text { pozitif enerji } 2\end{array}$ & $\begin{array}{l}\mathrm{f}=4, \\
\% 2.05\end{array}$ \\
\hline $\begin{array}{l}\text { 14. Müziği } \\
\text { sevdiren bir } \\
\text { kişi olarak } \\
\text { müzik öğret- } \\
\text { meni }\end{array}$ & $\begin{array}{l}\mathrm{f}=3 \\
\% 0.31\end{array}$ & Aşıc1 1, hemşire 1 , çilingir 1 & $\begin{array}{l}\mathrm{f}=3 \\
\% 1.54\end{array}$ \\
\hline $\begin{array}{l}\text { 15. Hayata } \\
\text { orijinallik } \\
\text { katan bir kişi } \\
\text { olarak müzik } \\
\text { öğretmeni }\end{array}$ & $\begin{array}{l}\mathrm{f}=3 \\
\% 0.31\end{array}$ & Karikatür 1 , uzaylı 1 , yeni bir dünya 1 & $\begin{array}{l}\mathrm{f}=3, \\
\% 1.54\end{array}$ \\
\hline
\end{tabular}




\section{Kategori 1. Seven, güven veren ve koruyan bir kişi olarak müzik öğretmeni}

Bu kategoriyi toplamda 246 (\%25.31) öğrenci ve 13 (\%6.67) metafor temsil etmektedir. Öğrenciler tarafından en s1k kullanılan metafor melektir $(\mathrm{f}=135)$. Bu metaforu anne $(\mathrm{f}=54)$ ve baba $(\mathrm{f}=38)$ metaforları takip etmektedir. $\mathrm{Bu}$ kategoriyi oluşturan metaforların öğrenciler tarafından vurgulanan özelliğine göre müzik öğretmeni, seven, güven veren ve koruyan bir kişi olarak görülmektedir. Örneğin; "Müzik öğretmeni melek gibidir. Çünkü iyi kalplidir." (Alparslan, 6, K). "Müzik öğretmeni anne gibidir. Çünkü şefkatlidir. Sever, korur ve benim iyiliğimi ister." (23 Nisan Havac1lar, 5, E). "Müzik öğretmeni baba gibidir. Çünkü bakar, büyütür. Bizi korur, kollar ve güven verir." (Atatürk, 5, K).

\section{Kategori 2. Sanatçı kişiliği ile müzik öğretmeni}

Bu kategoriyi toplamda 224 (\%23.04) öğrenci ve 17 (\%8.72) metafor temsil etmektedir. Öğrenciler tarafindan en sık kullanılan metafor bülbüldür $(\mathrm{f}=105)$. Bu metaforu şarkıcı $(\mathrm{f}=56)$ ve sanatçı $(\mathrm{f}=47)$ metaforları takip etmektedir. Bu kategoriyi oluşturan metaforların öğrenciler tarafından vurgulanan özelliğine göre müzik öğretmeni, sanatçı kişiliği ile öne çıkmaktadır. Örneğin; “Müzik ögrretmeni bülbül gibidir. Çünkü sesi güzeldir ve çok güzel şarkı söyler." (Kanunî Sultan Süleyman, 7, E). "Müzik öğretmeni şarkıcı gibidir. Çünkü her şarkıyı bilir ve çok güzel söyler." (Mevlâna, 6, E). "Müzik ögrretmeni sanatçı gibidir. Çünkü her şarkıyı çalabiliyor ve söyleyebiliyor." (Atatürk, 5, K).

\section{Kategori 3. Hayranlık duyulan bir kişi olarak müzik öğretmeni}

Bu kategoriyi toplamda 96 (\%9.88) öğrenci ve 23 (\%11.79) metafor temsil etmektedir. Öğrenciler tarafından en sık kullanılan metafor çiçektir $(\mathrm{f}=34)$. Bu metaforu takip eden metaforlardan bazıları prenses $(\mathrm{f}=18)$, gül $(\mathrm{f}=11)$, kahramanım $(\mathrm{f}=3)$ ve sihirbazdır $(\mathrm{f}=3)$. Bu kategoriyi oluşturan metaforların öğrenciler tarafından vurgulanan özelliğine göre müzik öğretmeni, hayranlık duyulan bir kişi olarak görülmektedir. Örneğin; "Müzik ögretmeni çiçek gibidir. Çünkü çok güzeldir." (Mevlâna, 6, E). "Müzik öğretmeni prenses gibidir. Çünkü tatl ve sevimlidir." (Alparslan, 5, E). "Müzik öğretmeni gül gibidir. Çünkü kokusu da kendisi de güzeldir." (Kemal Aydoğan, 7, E). "Müzik öğretmeni kahramanım gibidir. Çünkü müziğe bă̆lar." (Atatürk, 
6, E). “Müzik öğretmeni sihirbaz gibidir. Çünkü tek dokunuşla müzik aşılar.” (Atatürk, 5, K).

\section{Kategori 4. Eğlendirici yönü ile müzik öğretmeni}

$\mathrm{Bu}$ kategoriyi toplamda 95 (\%9.77) öğrenci ve 10 (\%5.13) metafor temsil etmektedir. Öğrenciler tarafindan en s1k kullanılan metafor komedyendir $(\mathrm{f}=54)$. Bu metaforu palyaço $(\mathrm{f}=11)$, müzik kutusu $(\mathrm{f}=10)$ ve stendapçı $(\mathrm{f}=6)$ metaforları takip etmektedir. Bu kategoriyi oluşturan metaforların öğrenciler tarafından vurgulanan özelliğine göre müzik öğretmeni, eğlenceli bir kişi olarak görülmektedir. Örneğin; "Müzik ögretmeni komedyen gibidir. Çünkü güldürür, eğlendirir.” (Kemal Aydoğan, 5, E). “Müzik ögretmeni palyaço gibidir. Çünkü komiktir ve şakalar yapar." (Atatürk, 6, K). "Müzik öğretmeni müzik kutusu gibidir. Çünkü melodilerle şenlendirir.” (Alparalslan, 7, K). "Müzik ögretmeni stendapçı gibidir. Çünkü esprileriyle bizi güldürür, eğlendirir." (Atatürk, 5, E).

\section{Kategori 5. Bilgi kaynağı bir kişi olarak müzik öğretmeni}

$\mathrm{Bu}$ kategoriyi toplamda $84(\% 8.64)$ öğrenci ve 36 (\%18.46) metafor temsil etmektedir. Öğrenciler tarafından en sık kullanılan metafor kitaptır $(\mathrm{f}=14)$. Bu metaforu radyo $(\mathrm{f}=8)$, müzik dâhisi $(\mathrm{f}=7)$ ve müzik kitabı $(\mathrm{f}=7)$ metaforları takip etmektedir. Bu kategoriyi oluşturan metaforların öğrenciler tarafından vurgulanan özelliğine göre müzik öğretmeni, bilgisi ile ön plana çıkmaktadır. Örneğin; "Müzik ögretmeni kitap gibidir. Çünkü bilgiyle aydinlatır. Bize ışılk tutar." (Kanunî Sultan Süleyman, 8, E). "Müzik ögretmeni radyo gibidir. Çünkü müzikleri çalar, söyler ve müzikler hakkında bilgiler verir.” (Alparslan, 7, K). “Müzik ögretmeni müzik dâhisi gibidir. Çünkü müzik hakkında bilmediği şey yoktur.” (Atatürk, 7, E).

\section{retmeni \\ Kategori 6. Yol gösterici ve yönlendirici bir kişi olarak müzik öğ-}

Bu kategoriyi toplamda 79 (\%8.13) öğrenci ve 27 (\%13.85) metafor temsil etmektedir. Öğrenciler tarafından en sık kullanılan metafor güneştir $(\mathrm{f}=15)$. Bu metaforu rehber $(\mathrm{f}=11)$ ve pusula $(\mathrm{f}=10)$ metaforları takip etmektedir. Bu kategoriyi oluşturan metaforların öğrenciler tarafindan vurgulanan özelliğine göre müzik öğretmeni, doğru yolu gösteren ve yönlendiren bir kişi olarak görülmektedir. Örneğin; "Müzik öğretmeni güneş gibidir. Çünkü aydınlatır, ışık saçar." (23 Nisan Havacılar, 8, K). "Müzik öğretmeni rehber gibidir. Çünkü müziğe giden yolu gösterir." (Alparslan, 7, E). “Müzik öğ- 
retmeni pusula gibidir. Çünkü yön gösterir. Doğru yola götürür." (Atatürk, 8, $\mathrm{K})$.

\section{Kategori 7. Sevilen bir kişi olarak müzik öğretmeni}

$\mathrm{Bu}$ kategoriyi toplamda 48 (\%4.94) öğrenci ve 20 (\%10.26) metafor temsil etmektedir. Öğrenciler tarafindan en sık kullanılan metafor pamuk şekerdir ( $\mathrm{f}=12)$. Bu metaforu çikolata $(\mathrm{f}=3)$ ve adamın dibi $(\mathrm{f}=2)$ metaforları takip etmektedir. Bu kategoriyi oluşturan metaforların öğrenciler tarafından vurgulanan özelliğine göre müzik öğretmeni, sevilen bir kişi olarak görülmektedir. Örneğin; "Müzik öğretmeni pamuk şeker gibidir. Çünkü bize yumuşak davranır. Çok tatlı birisidir benim öğretmenim." (Alparslan, 5, E). "Müzik öğretmeni çikolata gibidir. Çünkü o çok tatlıdır." (23 Nisan Havac1lar, 6, K). "Müzik öğretmeni adamın dibi gibidir. Çünkü sevecen ve iyi kalplidir." (Atatürk, 7, E).

\section{Kategori 8. Sevilmeyen bir kişi olarak müzik öğretmeni}

Bu kategoriyi toplamda 38 (\%3.91) öğrenci ve 17 (\%8.72) metafor temsil etmektedir. Öğrenciler tarafından en sık kullanılan metafor papağandır $(\mathrm{f}=10)$. Bu metaforu bomba $(\mathrm{f}=3)$ ve kutu kola $(\mathrm{f}=2)$ metaforları takip etmektedir. Bu kategoriyi oluşturan metaforların öğrenciler tarafından vurgulanan özelliğine göre müzik öğretmeni, sert bir mizaca sahip, korkulan ve sevilmeyen bir kişi olarak görülmektedir. Örneğin; "Müzik ögretmeni papağan gibidir. Çünkü çok konuşur ve sürekli tekrar ettirir." (Atatürk, 5, E). "Müzik ögretmeni bomba gibidir. Çünkü sinirlidir. Her an patlayabilir." (Mevlâna, 6, E). "Müzik ögretmeni kutu kola gibidir. Çünkü kolayı çalkalayınca patlar. Öğretmenimiz de çalışmadan gelince, dersi dinlemeyince patlar." (Kanunî Sultan Süleyman, 7, K).

\section{Kategori 9. Şifa veren bir kişi olarak müzik öğretmeni}

$\mathrm{Bu}$ kategoriyi toplamda $23(\% 2.37)$ öğrenci ve 5 (\%2.56) metafor temsil etmektedir. Öğrenciler tarafından en sık kullanılan metafor terapisttir $(\mathrm{f}=8)$. Bu metaforu psikolog $(\mathrm{f}=6)$ ve çamaşır makinası $(\mathrm{f}=6)$ metaforları takip etmektedir. Bu kategoriyi oluşturan metaforların öğrenciler tarafından vurgulanan özelliğine göre müzik öğretmeni, şifa veren bir kişi olarak görülmektedir. Örneğin; "Müzik ögretmeni terapist gibidir. Çünkü sıkıntımı paylaşır. Beni rahatlatır." (Alparslan, 8, K). "Müzik ögrretmeni psikolog gibidir. Çünkü duygularımızı anlar. Bizi şarkılarıyla rahatlatır." (Kemal Aydoğan, 7, 
K). “Müzik öğretmeni çamaşır makinası gibidir. Çünkü kafamızdaki olumsuzluklart yıkar, temizler." (23 Nisan Havacılar, 8, K).

\section{Kategori 10. Öğretici yönü ile müzik öğretmeni}

$\mathrm{Bu}$ kategoriyi toplamda $14(\% 1.44)$ öğrenci ve $8(\% 4.10)$ metafor temsil etmektedir. Öğrenciler tarafından en sık kullanılan metafor meyve veren ağaçtır $(\mathrm{f}=6)$. Bu metaforu bahçıvan $(\mathrm{f}=2)$ ve heykeltıraş $(\mathrm{f}=1)$ metaforları takip etmektedir. Bu kategoriyi oluşturan metaforların öğrenciler tarafindan vurgulanan özelliğine göre müzik öğretmeni, öğretici yönü ile öne çıkmaktadır. Örneğin; "Müzik ögretmeni meyve veren ă̆aç gibidir. Çünkü bizlere bilgiler verir." (Atatürk, 8, E). "Müzik ögretmeni bahçıvan gibidir. Çünkü bahçıvan parklarda ă̆açları, çiçekleri yetiştirir. Öğretmenimiz de bizi yetiştirir." (Mevlâna, 7, E). "Müzik öğretmeni heykeltıraş gibidir. Çünkü heykeltıraş taşlara şekil verir. Öğretmenimiz de bizlere şekil verir." (Atatürk, $8, \mathrm{~K})$.

\section{Kategori 11. Hayata renk katan kişi olarak müzik öğretmeni}

Bu kategoriyi toplamda $8(\% 0.82)$ öğrenci ve $6(\% 3.08)$ metafor temsil etmektedir. Öğrenciler tarafından en sık kullanılan metafor kelebektir ( $\mathrm{f}=3$ ). $\mathrm{Bu}$ metaforu ilkbahar ( $\mathrm{f}=1)$ ve gökkuşağı $(\mathrm{f}=1)$ metaforları takip etmektedir. $\mathrm{Bu}$ kategoriyi oluşturan metaforların öğrenciler tarafindan vurgulanan özelliğine göre müzik öğretmeni, hayatı renklendiren bir kişi olarak görülmektedir. Örneğin; "Müzik ögrretmeni kelebek gibidir. Çünkü hayatımıza renk katar." (Kemal Aydoğan, 8, K). "Müzik öğretmeni ilkbahar gibidir. Çünkü ilkbaharda her yer yeşerir. Rengârenk çiçekler açar. Öğretmenimiz de bizim dersimizi renklendirir." (Alparslan, 8, E). "Müzik öğretmeni gökkuşă̆l gibidir. Çünkü renkli biridir.” (23 Nisan Havacılar, 6, E).

\section{Kategori 12. Değerli bir kişi olarak müzik öğretmeni}

Bu kategoriyi toplamda $6(\% 0.62)$ öğrenci ve $3(\% 1.54)$ metafor temsil etmektedir. Öğrenciler tarafından en sık kullanılan metafor mücevherdir $(\mathrm{f}=4)$. Bu metaforu pirlanta $(\mathrm{f}=1)$ ve başımın tacı $(\mathrm{f}=1)$ metaforları takip etmektedir. Bu kategoriyi oluşturan metaforların öğrenciler tarafından vurgulanan özelliğine göre müzik öğretmeni, bilgisi ve kişiliği ile değerli bir öğretmen olarak görülmektedir. Örneğin; "Müzik ögretmeni mücevher gibidir. Çünkü değerlidir. Eşi benzeri yoktur." (Mevlâna, 6, K). "Müzik öğretmeni pırlanta gibidir. Çünkü benim için çok değerlidir." (Kemal Aydoğan, 8,K). 
"Müzik ögretmeni başımın tacı gibidir. Çünkü o çok değerli bir öğretmendir." (23 Nisan Havacilar, 8, E).

\section{Kategori 13. Mutluluk veren bir kişi olarak müzik öğretmeni}

Bu kategoriyi toplamda 5 (\%0.51) öğrenci ve 4 (\%2.05) metafor temsil etmektedir. Öğrenciler tarafından en sık kullanılan metafor pozitif enerjidir $(\mathrm{f}=2)$. Bu metaforu pozitif elektron $(\mathrm{f}=1)$ ve dizi sezon finali $(\mathrm{f}=1)$ metaforları takip etmektedir. Bu kategoriyi oluşturan metaforların öğrenciler tarafindan vurgulanan özelliğine göre müzik öğretmeni, mutluluk veren bir kişi olarak görülmektedir. Örneğin; “Müzik öğretmeni pozitif enerji gibidir. Çünkü derste bize mutluluk saçar." (Atatürk, 7, K). "Müzik öğretmeni pozitif elektron gibidir. Çünkü pozitif enerji verir." (Kemal Aydoğan, 8, K). "Müzik öğretmeni dizi sezon finali gibidir. Çünkü ders bittiğinde hep mutlu ayrllırım." (Alparslan, 8, K).

\section{Kategori 14. Müziği sevdiren kişi olarak müzik öğretmeni}

Bu kategoriyi toplamda $3(\% 0.31)$ öğrenci ve $3(\% 1.54)$ metafor temsil etmektedir. Öğrenciler tarafından kullanılan metaforlar aşıcı ( $\mathrm{f}=1)$, hemşire $(\mathrm{f}=1)$ ve çilingir $(\mathrm{f}=1)$ metaforlarıdır. Bu kategoriyi oluşturan metaforların öğrenciler tarafından vurgulanan özelliğine göre müzik öğretmeni, müziği sevdiren bir kişi olarak görülmektedir. Örneğin; "Müzik ögrretmeni aşıcı gibidir. Çünkü bize müziğin güzelliklerini aşılar." (Kemal Aydoğan, 8, K). "Müzik öğretmeni hemşire gibidir. Çünkü müzik sevgisini aşılar." (23 Nisan Havacılar, 8, E). "Müzik öğretmeni çilingir gibidir. Çünkü müzik kapısını açar. Müziği sevdirir.” (Atatürk, 7, K).

\section{Kategori 15. Hayata orijinallik katan bir kişi olarak müzik öğ- retmeni}

Bu kategoriyi toplamda $3(\% 0.31)$ öğrenci ve 3 (\%1.54) metafor temsil etmektedir. Öğrenciler tarafından kullanılan metaforlar karikatür (f=1), uzaylı $(\mathrm{f}=1)$ ve yeni bir dünya $(\mathrm{f}=1)$ metaforlarıdır. Bu kategoriyi oluşturan metaforların öğrenciler tarafından vurgulanan özelliğine göre müzik öğretmeni, hayata orijinallik katan bir kişi olarak görülmektedir. Örneğin; "Müzik öğretmeni karikatür gibidir. Çünkü değişik esprileri vardır. Bazen bizleri düşündürür." (Mevlâna, 6, K). "Müzik öğretmeni uzayl gibidir. Çünkü bizi başka dünyalara götürür." (Kanunî Sultan Süleyman, 8, K). "Müzik öğretmeni yeni bir dünya gibidir. Çünkü yeni şeyler anlatır.” (Atatürk, 7, E). 


\section{Sonuç, Tartışma ve Öneriler}

$\mathrm{Bu}$ çalışma, ortaokul öğrencilerinin müzik dersi ve müzik öğretmenine ilişkin algılarının metaforlar yoluyla analiz edilmesi amacıyla yapılmıştır. Çalışma sonucunda ortaokul öğrencilerinin müzik dersine ilişkin olarak toplam 277 adet ve müzik öğretmenine ilişkin olarak da toplam 195 adet metafor ürettikleri belirlenmiştir. Her bir boyut için üretilen metaforlar ortak özellikleri bakımından incelenerek müzik dersine ilişkin metaforlar 13, müzik öğretmenine ilişkin metaforlar da 15 farklı kavramsal kategori altında toplanmıştır. Çalışmada üretilen metafor sayılarının ve kavramsal kategori sayılarının fazla oluşu, öğrencilerin müzik dersi ve müzik öğretmeninin çok yönlü özellikler taşıdığı algısına sahip olduklarını göstermektedir.

Çalışma sonucuna göre müzik dersine ilişkin kavramsal kategorilerden "eğlendiren ve mutluluk veren bir ders olarak müzik dersi" ( $\mathrm{f}=558, \% 57.41)$ kategorisinin, öğrencilerin en sık katılım gösterdiği kategori olduğu belirlenmiştir. Bu kategoriyi "arındıran, dinlendiren ve huzur veren bir ders olarak müzik dersi" ( $\mathrm{f}=98, \% 10.08)$, "karmaşık bir ders olarak müzik dersi” ( $\mathrm{f}=87$, \%8.95) ile "zengin öğrenme durumlarını içeren bir ders olarak müzik dersi" ( $\mathrm{f}=54, \% 5.55)$ kategorilerinin izlemekte olduğu tespit edilmiştir. Çalışmada müzik öğretmenine ilişkin kavramsal kategorilerden öne çıkan kategorilerin "seven, güven veren ve koruyan bir kişi olarak müzik öğretmeni" ( $\mathrm{f}=246$, \%25.31), "sanatçı kişiliği ile müzik öğretmeni" (f=224, \%23.04) ve "hayranlık duyulan bir kişi olarak müzik öğretmeni”" (f=96, \%9.88) olduğu bulunmuştur.

Çalışmadan elde edilen sonuçlara göre öğrenciler müzik dersini ilk sırada eğlendiren ve mutluluk veren bir ders olarak görmektedirler. Öğrencilerin müzik dersinin eğlendiren ve mutluluk veren bir ders olduğuna ilişkin ürettikleri metaforlardaki çeşitlilik $(\% 36.46)$ ve bu metaforlara katılım düzeyleri (\%57.41), müzik dersinin yaşantılarında öncelikle eğlendirici ve mutluluk verici özellikleriyle yer aldığını göstermektedir. Öğrenciler müzik dersini ikinci sirada (\%10.08) arındıran, rahatlatan ve huzur veren bir ders olarak görmektedirler. Öğrenciler için müzik dersi sıkıntılardan kurtaran bir cankurtaran, rahatlatan bir terapi merkezi, dinlendiren uyku ve huzur buldukları evleri gibidir.

Çalışmanın sonuçlarına göre öğrenciler ( $\mathrm{f}=54, \% 5.55)$ müzik dersini çeşitli şarkıları ve çalgıları öğrendikleri zengin öğrenme durumlarını içeren 
bir ders olarak algılamaktadırlar. Öğrencilere göre ( $\mathrm{f}=50, \% 5.14)$ müzik dersi öğreten, eğiten ve yönlendiren bir derstir. Bilgi dükkânı, bilgi kaynağı, bilmece, bulmaca, kitap, kültür gezisi gibi bilgi verir. Ay ışı̆̆ı, güneş, yıldız gibi yönlendirir. Hayatın dersi gibidir. Müzik dersi farklı müziklerle farklı dünyaların keşfedilmesini sağlar ve bakış açısını zenginleştirir ( $\mathrm{f}=18, \% 1.85)$. Müzik dersi temiz hava, yağmur, yemek vb. kadar gereklidir ( $\mathrm{f}=16, \% 1.65)$. Müzik dersi hayatı ve toplumları yansitır. Duyguların müzikle dile getirilmesini sağlar ( $\mathrm{f}=10, \% 1.03)$. Müzik dersi müzikle buluşmayı sağlayan köprü, yol vb. bir araçtır ( $\mathrm{f}=3, \% 0.31)$. Öğrenciler bu derste çalıp söyleyerek sürekli aktif olmaktadır ( $\mathrm{f}=2, \% 0.21)$.

$\mathrm{Bu}$ çalışmada müzik dersine ilişkin üretilen metaforların çoğunlukla olumlu nitelikler taşıyor olması ( $\mathrm{f}=844, \% 86.83$ ), öğrencinin yaşantısında müzik dersinin ne denli önemli bir yer kapladığına işaret etmektedir. Buna karşın oluşturulan kategoriden de anlaşılabileceği gibi müzik dersinin süresi öğrencilere yetmemektedir ( $\mathrm{f}=35, \% 3.60)$. İlgili çalışmaların sonuçları incelendiğinde öğrencilerin müzik dersi dışındaki derslerle ilgili ürettikleri metaforlarda ders süresinin yetersizliğini vurgulamadıkları dikkati çekmektedir (Ada, 2013; Çifçi, 2015; Mertol, Doğdu ve Yılar, 2013; Soysal ve Afacan, 2012). Bu bakımdan müzik ders saatinin artırılmasına ilişkin düzenlemeler yapılmas1 gerekmektedir.

Umuzdaş ve Umuzdaş'ın (2013) çalışmasından elde edilen sonuçlar, bu çalışmadan elde edilen sonuçlarla benzerlik göstermektedir. Umuzdaş ve Umuzdaş'ın çalışmasında, sınıf öğretmeni adaylarının müzik dersine ilişkin algılarının metaforlar aracılığıyla ortaya çıkarılması amaçlanmıştır. Çalışmanın sonuçlarına göre müzik dersine ilişkin ilk sırada oluşturulan kategorilerin eğlenceli, ihtiyaç duyulan, dinlendirici ve geliştirici kategorileri olduğu bulunmuştur.

$\mathrm{Bu}$ çalışmadan elde edilen sonuçlara göre müzik dersi bir kısım öğrenci ( $\mathrm{f}=128, \% 13.17)$ tarafından olumsuz niteliklerle tanımlanmıştır. Buna göre bazı öğrenciler ( $\mathrm{f}=87, \% 8.95)$ müzik dersini karmaşık bir ders olarak algılamakta, bazı ögrenciler ( $\mathrm{f}=10, \% 1.03)$ müzik dersinde başarılı olmak için yetenekli olunması gerektiğini düşünmekte, bazı öğrenciler de ( $\mathrm{f}=31, \% 3.19)$ müzik dersinin olumsuz öğretme-öğrenme ortamına sahip olduğunu ifade etmektedir. Öğrencilerin müzik dersinde kendilerini çaba göstererek ve çalışarak başarılı olabilecekleri bir öğretme-öğrenme ortamında olduklarını his- 
setmeleri, bu algılarının değiştirilmesini sağlayabilir. Öğretme-öğrenme ortamında bu husus dikkate alınarak gerçekleştirilecek düzenlemeler, öğrencilerin müzik dersindeki başarı hedefi yönelimlerini performans odaklı hedef yöneliminden öğrenme odaklı hedef yönelimine dönüştürebilir.

Bu çalışmanın sonuçları Ames ve Archer'in (1988) çalışmalarında ortaya koyduğu sonucu destekler niteliktedir. Ames ve Archer'in (1988) ça1ışmalarında sınıf içerisinde öğrenme yöneliminin önemini algılayan öğrencilerin, daha etkili stratejiler kullandığı, zorlayıcı görevleri tercih ettiği, sınıfa karşı daha pozitif bir tutum sergilediği ve başarının, bir kişinin gösterdiği çabanın sonucunda ortaya çıktığına dair daha güçlü bir inanca sahip olduğu bildirilmiştir. Performans hedeflerini dikkat çekici olarak algılayan öğrencilerin ise kendi becerilerini olumsuz bir şekilde değerlendirdikleri ve başar1sızlığı beceri yoksunluğuna bağladıkları bulunmuştur. Church, Elliot ve Gable'ın (2001) algılanan sınıf ortamı ve başarı hedefi değişkenlerini performans ve içe yönelik motivasyonun göstergeleri olarak test ettikleri çalışmalarının sonuçları da açık bir şekilde göstermiştir ki, algılanan sınıf ortamı başarı hedefi yönelimini etkilemektedir. Bu bakımdan müzik dersine ilişkin olumsuz öğretme-öğrenme ortamı algısının düzeltilmesi hususunda tedbirler alınması gerekmektedir.

Çalışmanın sonuçlarına göre müzik öğretmenine ilişkin oluşturulan 15 kategoriden 14'ünün olumlu nitelik taşıdığı belirlenmiştir. Öğrenciler müzik öğretmenini ilk sırada ( $\mathrm{f}=246, \% 25.31$ ) seven, güven veren ve koruyan bir kişi olarak algılamaktadır. Bu durum öğrencilerin müzik öğretmeninin insanî özelliklerine atfeden metaforlara öncelik verdiklerini göstermektedir. Öğrenciler ikinci sırada ( $\mathrm{f}=224, \% 23.04)$ müzik öğretmeninin meslekî niteliklerine vurgu yapan metaforları kullanmışlardır. Buna göre müzik öğretmeni güzel sesli, güzel şarkı söyleyen ve çalgısına hâkim bir kişidir. Öğrenciler üçüncü sırada ( $\mathrm{f}=96, \% 9.88)$ müzik öğretmenini hayranlık duyulan bir kişi olarak görmektedir. Bu kategoride müzik öğretmeninin hem fiziksel (manken, prenses gibi) hem meslekî (büyücü, sihirbaz gibi) özelliklerine vurgu yapan metaforlar üretilmiştir. Bir diğer kategoriye göre öğrenciler müzik öğretmenini eğlendirici bir kişi olarak görmektedir ( $\mathrm{f}=95, \% 99.77$ ). Müzik öğretmeni hem esprili kişiliğiyle (komedyen, tiyatro sanatçısı gibi) hem de çalıp söylemesiyle (canlı müzik programı, müzik çalar gibi) öğrencileri eğlendirmektedir. Öğrenciler müzik öğretmenini bilgi kaynağı bir kişi olarak algılamak- 
tadır ( $\mathrm{f}=84, \% 8.64)$. Müzik öğretmeninin meslekî özelliklerine vurgu yapan metaforlardan oluşan bu kategoride, müzik öğretmeni müzik hakkında her şeyi bilen bir kişi olarak görülmektedir. Öğrenciler müzik öğretmenini yol gösteren ve yönlendirici bir kişi olarak algılamaktadır ( $\mathrm{f}=79, \%$ \%.13). $\mathrm{Bu}$ kategoride üretilen metaforlara göre müzik öğretmeni hem doğru yolu (pusula gibi), hem de müziğge giden yolu (rehber, müzik lambası gibi) gösterir. Öğrencilerin müzik öğretmenini sevilen bir kişi olarak gördükleri bir diğer kategoride, müzik öğretmeninin kişisel özelliklerini öne çıkaran (adamın hası, kankam, pamuk şeker gibi) metaforların üretildiği görülmektedir ( $\mathrm{f}=48$, \%4.94). Öğrenciler müzik öğretmenini müzikle şifa veren bir kişi olarak algılamaktadır ( $\mathrm{f}=23, \% 2 \cdot 37$ ). Öğrenciler müzik öğretmenini öğretici bir kişi olarak görmektedir ( $\mathrm{f}=14, \% 1.44)$. Öğrencilere göre müzik öğretmeni hayata renk katan bir kişidir ( $\mathrm{f}=8, \% 0.82$ ). Eşi benzeri olmayan değerli bir öğretmendir ( $\mathrm{f}=6, \% 0.62)$. Müzik öğretmeni öğrencilerin ders süresince mutlu olmalarını ve dersten mutlu bir şekilde ayrılmalarını sağlar $(\mathrm{f}=5, \% 0.51)$. Müzik öğretmeni müziğin güzelliklerini öğrencilerine aşılayarak müziği sevdirir ( $\mathrm{f}=3, \% 0.31$ ). Müzik öğretmeni güldürürken düşündüren, yeni şeyler anlatan bu özellikleriyle de hayata orijinallik katan bir öğretmendir ( $\mathrm{f}=3$, $\% 0.31)$.

Çalışmadan elde edilen sonuçlara göre öğrencilerin tamamına yakın bir kısmı ( $\mathrm{f}=934, \% 96.09)$ müzik öğretmenini olumlu şekilde nitelendirmiştir. Buna karşın kısıtlı sayıdaki öğrencinin ise ( $\mathrm{f}=38, \% 3.91)$ müzik öğretmenini sevilmeyen bir kişi olarak nitelendirdikleri tespit edilmiştir. Bu durum müzik öğretmeninin kişilik özelliklerine ilişkin algıyla bağlantılı olabilir.

$\mathrm{Bu}$ çalışmadan elde edilen sonuçlar bütüncül bir bakış açısıyla incelendiğinde ortaokul öğrencilerinin müzik dersi ve müzik öğretmenine ilişkin algılarının açıklanmasında bu kavramların farklı yönlerine vurgu yapan pek çok metafor ürettikleri görülmektedir. Metaforlar, müzik öğretmenlerinin kendi öğrencilerini tanımaları ve dersleriyle ilgili algılarını açığa çıkarmaları açısından etkili birer araçtır. Müzik öğretmenine ilişkin algının açığa çıkarılması, öğretmenin içe dönük bir değerlendirme yapmasına ve derse ilişkin öğretme-öğrenme ortamını etkin bir şekilde düzenlemesine katkı sağlayabilir. Araştırmacılar bu çalışmada oluşturulan kategorilere dayalı olarak müzik dersi ve müzik öğretmeniyle ilgili algıların belirlenmesinde kullanılabilecek 
ölçekler geliştirebilir. Ayrıca müzik dersi ve müzik öğretmenine ilişkin alg1ların belirli değişkenlerle ilişkilerinin araştırıldığı çalışmalar yapılabilir.

\section{Kaynakça}

Ada, S. (2013). Öğrencilerin matematik dersine ve matematik öğretmenine yönelik algılarının metaforlar yardımıyla belirlenmesi. Yayımlanmamış yüksek lisans tezi, Gazi Üniversitesi, Eğitim Bilimleri Enstitüsü.

Afacan, Ö. (2011). Fen bilgisi öğretmen adaylarının "fen" ve "fen ve teknoloji öğretmeni” kavramlarına yönelik metafor durumları. e-Journal of New World Sciences Academy Education Sciences, 6(1), 1242-1254.

Akça-Berk, N., Gültekin, F. ve Çençen, N. (2015). Sosyal bilgiler öğretmen adaylarının sosyal bilgiler dersine ve sosyal bilgiler öğretmenine ilişkin metaforları. Ahi Evran Üniversitesi Kırşehir Eğitim Fakültesi Dergisi (KEFAD), 16(1), 183-199.

Akkaya, E. (2012). Ortaöğretim ögrrenci ve ögretmenlerinin okul ve ideal okul algılarının metafor yoluyla analizi. Yayımlanmamış yüksek lisans tezi, Gazi Üniversitesi, Eğitim Bilimleri Enstitüsü.

Ames, C. ve Archer, J. (1988). Achievement goals in the classroom: students' learning strategies and motivation processes. Journal of Educational Psychology, 80(3), 260-267.

Asaman, E. (2013). Özel eğitim kurumlarındaki öğretmen ve öğrencilerin birbirlerine yönelik metaforik algıları. Yayımlanmamış yüksek lisans tezi, Mersin Üniversitesi, Eğitim Bilimleri Enstitüsü.

Aydıner-Uygun, M. (2015). Öğretmen adaylarının geleneksel müzik türlerine ilişkin algılarının metaforlar aracılığıyla incelenmesi. Afyon Kocatepe Üniversitesi Akademik Müzik Araştırmaları Dergisi, 1(1), 59-76.

Babacan, E. (2014). AGSL öğrencilerinin müzik kavramına ilişkin algıları: Metafor analizi. Ĕgitim ve Öğretim Araştırmalar Dergisi, 3(1), 124-132.

Bahar-Güner, H. Ö., Tunca, N., Alkın-Şahin, S. ve Oğuz, A. (2015). Öğret- 
men adaylarının öğretmen eğitimcisine ilişkin metaforik algıları. $P e$ gem Ĕ̈itim ve Öğretim Dergisi, 5(4), 419-444.

doi: $10.14527 /$ pegegog.2015.023

Balcı, A. (2015). Sosyal bilimlerde araştırma (11. bask1). Ankara: Pegem Akademi.

Cerit, Y. (2008). Öğretmen kavramı ile ilgili metaforlara ilişkin öğrenci, öğretmen ve yöneticilerin görüşleri. Türk Eğitim Bilimleri Dergisi, 6(4), 693-712.

Church, M. A., Elliot, A. J. ve Gable, S. L. (2001). Perceptions of classroom environment, achievement goals, and achievement outcomes. Journal of Educational Psychology, 93(1), 43-54.

Çifçi, T. (2015). Üstün yetenekli öğrencilerin coğrafya dersine ilişkin algıları. e-International Journal of Educational Research, 6(3), 87-100.

Çulha-Özbaş, B. (2012). "Sosyal bilgiler öğretmeni olarak, ben kimim?" sosyal bilgiler öğretmenlerinin mesleki kimliklerine yönelik görüşlerinin metafor analizi yoluyla incelenmesi. Turkish Studies, 7(2), 821-838.

Çulha-Özbaş, B. ve Aktekin, S. (2013). Tarih öğretmen adaylarının tarih öğretmenliğine ilişkin inançlarının metafor analizi yoluyla incelenmesi. Eğitimde Kuram ve Uygulama, 9(3), 211-228.

Demirci-Güler, M. P. (2012). Sınıf öğretmeni adaylarının fen ve teknoloji dersine ilişkin metaforik tanımlamaları. Elektronik Sosyal Bilimler Dergisi, 11(41), 53-63.

Dinç-Altun, Z. (2014, Nisan). Müzik öğretmenliği programı öğretmen adaylarının piyano dersi kavramına ilişkin metafor algıları. İpek yolunda müzik kültürü ve eğitimi konferansında sunulan bildiri, İstanbul, Türkiye.

Dumanl1-Kadızade, E. (2014). Aktif öğrenmede bir teknik; metafor uygulaması "Türkçe öğretmen adaylarının Türkçe dersi algıları üzerine". In- 
ternational Journal of Language Academy. 2(4), 68-85.

Ekiz, D. ve Koçyiğit, Z. (2013). Sınıf öğretmenlerinin “öğretmen” kavramına ilişkin metaforlarının tespit edilmesi. Kastamonu Eğitim Dergisi, 21(2), 439-458.

Eminoğlu-Küçüktepe, S. ve Gürültü, E. (2014). Öğretmenlerin “yapılandırmacı öğretmen" kavramına ilişkin algılarına yönelik metafor çalışması örneği. Abant İzzet Baysal Üniversitesi Eğitim Fakültesi Dergisi, 14(2), 282-305.

Girmen, P. (2007). İlköğretim öğrencilerinin konuşma ve yazma sürecinde metaforlardan yararlanma durumları. Yayımlanmamış doktora tezi, Anadolu Üniversitesi, Eğitim Bilimleri Enstitüsü.

Kalyoncu, R. (2012). Görsel sanatlar öğretmeni adaylarının öğretmenlik kavramına ilişkin metaforları. Mustafa Kemal Üniversitesi Sosyal Bilimler Enstitüsü Dergisi, 9(20), 471-484.

Karasar, N. (2013). Bilimsel araştırma yöntemi (25. baskı). Ankara: Nobel A Yayınc1lik.

Koca, Ş. (2012). The pre-school teacher candidates' metaphorical thinking about the concept of music learning. Procedia-Social and Behavioral Sciences 47, 1485-1489.

Koç, E. S. (2014). Sınıf öğretmeni adaylarının öğretmen ve öğretmenlik mesleği kavramlarına ilişkin metaforik algıları. İnönü Üniversitesi Eğitim Fakültesi Dergisi, 15(1), 47-72.

doi: 10.17679/iuefd.79408

Lakoff, G. ve Johnson, M. (2005). Metaforlar hayat, anlam ve dil (G. Y. Demir, Çev.). İstanbul: Paradigma Yayıncılık. (Orijinal çalışma basım tarihi 1980).

Mentiş-Köksoy, A. (2015). Primary school teacher candidates' perceptions related to the concept of music. International Review of Social Sciences and Humanities, 9(2), 9-15. 
Merriam, S. (2013). Nitel araştırma desen ve uygulama için bir rehber (S. Turan, Çev.). Ankara: Nobel A Yayıncılık. (Orijinal çalışma basım tarihi 2009).

Mertol, H., Doğdu, M. ve Yılar, B. (2013). Üstün zekâlı ve yetenekli öğrencilerin sosyal bilgiler dersine ilişkin metaforik algıları. Üstün Yetenekli Eğitimi Araştırmaları Dergisi, 1(3), 176-183.

Mete, Y. A. (2013). Okul uygulaması dersine yönelik öğretmen adayı, öğretmen ve okul yöneticilerinin sahip oldukları metaforlar. Ögretmen Eğitimi ve Ë̆itimcileri Dergisi, 2(2), 249-274.

Mustan-Dönmez, B. ve Karaburun, D. (2013). Türk halk müziği sözlerinde metaforik anlatım geleneği. Turkish Studies, 8(4), 1081-1097.

Oflaz, G. (2011, Nisan). İlköğretim öğrencilerinin “matematik" ve "matematik öğretmeni" kavramlarına ilişkin metaforik algıları. $2^{\text {nd }}$ international conference on new trends in education and their implications içinde (884-893). Antalya, Türkiye.

Özkul, M. K. (2013, Ekim). Müzik Metaforları. 1. uluslararası müzik araştırmaları sempozyumu “müzik ve kültürel doku” içinde (312-320). Trabzon, Türkiye.

Saban, A. (2004). Giriş düzeyindeki sınıf öğretmeni adaylarının "öğretmen" kavramına ilişkin ileri sürdükleri metaforlar. Türk Eğitim Bilimleri Dergisi, 2(2), 131-155.

Saban, A. (2011). Bilgisayar öğretmeni adaylarının "okul” ve "bilgisayar öğretmeni” kavramlarına ilişkin zihinsel imgeleri. Kuram ve Uygulamada Eğitim Bilimleri, 11(1), 423-446.

Soysal, D. ve Afacan, Ö. (2012). İlköğretim öğrencilerinin "fen ve teknoloji dersi" ve "fen ve teknoloji öğretmeni" kavramlarına yönelik metafor durumları. Mustafa Kemal Üniversitesi Sosyal Bilimler Enstitüsü Dergisi, 9(19), 287-306.

Şengül, S., Katranc1, Y. ve Gerez-Cantimer, G. (2014). Ortaokul öğrencile- 
rinin "matematik öğretmeni” kavramına ilişkin metafor algıları. International Journal of Social Science, 25(1), 89-111. doi:10.9761

Umuzdaş, S. ve Umuzdaş, M. S. (2013). Sınıf öğretmenliği öğrencilerinin müzik dersine ilişkin algılarının metafor yoluyla belirlenmesi. International Journal of Human Sciences, 10(1), 719-729.

Wells-Yalçın, Ş. (2015). Görsel sanatlar öğretmeni adaylarının öğretmen ve sanatçı algısına ilişkin metafor analizi. Hacettepe Üniversitesi Eğitim Fakültesi Dergisi, 30(3), 160-175.

Yıldırım, A. ve Şimşek, H. (2006). Sosyal bilimlerde nitel araştırma yöntemleri. Ankara: Seçkin Yayıncılık.

Zeren, M. G. (2015). Üniversite öğrencilerinin gözü ile coğrafya eğitimcisi: Bir olgubilim araştırması. Doğu Coğrafya Dergisi, 20(33), 189-208. 